\title{
Why Prison?: An Economic Critique
}

\author{
Peter N. Salib*
}

This Article argues that we should not imprison people who commit crimes. This is true despite the fact that essentially all legal scholars, attorneys, judges, and laypeople see prison as the sine qua non of a criminal justice system. Without prison, most would argue, we could not punish past crimes, deter future crimes, or keep dangerous criminals safely separate from the rest of society. Scholars of law and economics have generally held the same view, treating prison as an indispensable tool for minimizing social harm. But the prevailing view is wrong. Employing the tools of economic analysis, this Article demonstrates that prison imposes enormous but well-hidden societal losses. It is therefore a deeply inefficient device for serving the utilitarian aims of the criminal law system-namely, optimally deterring bad social actors while minimizing total social costs. The Article goes on to engage in a thought experiment, asking whether an alternative system of criminal punishment could serve those goals more efficiently. It concludes that economically superior alternatives to prison are currently available. The alternatives are practicable. They plausibly comport with our current legal rules and more general moral principles. They could theoretically be implemented tomorrow, and, if we wished, we could bid farewell forever to our sprawling, socially-suboptimal system of imprisonment.

DOI: https://dx.doi.org/10.15779/Z38M902321

Copyright (C) 2017 Regents of University of California

* Associate, Sidley Austin LLP. Special thanks to Jonathan S. Masur and Anup Malani for their comments and critiques. 
Introduction 113

I.The Law and Economics View of Criminal Law 117

A. Optimal Deterrence......................................................... 118

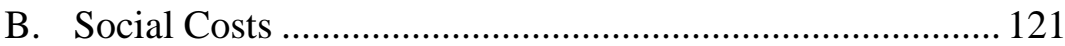

C. Perverse Incentives ............................................................... 123

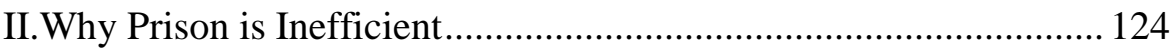

A. Prison's Social Costs ........................................................... 125

1. Administrative Costs ....................................................... 125

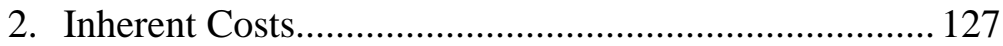

B. Prison's Perverse Incentives .............................................. 132

C. Prison and Optimal Deterrence......................................... 137

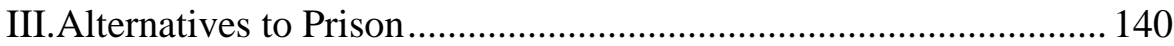

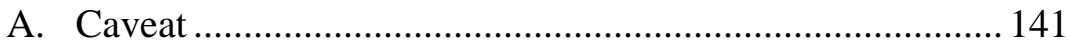

B. A First Pass at Efficiency: More Efficient Prisons ............. 142

C. The Efficient System ...................................................... 146

1. The Efficient System Avoids Unnecessary Intrinsic Social Losses ................................................................. 147

2. The Efficient System Can Reduce Administrative Costs and Perverse Incentives ...................................... 148

3. The Efficient System Does Not Conflict with Optimal Deterrence ................................................ 150

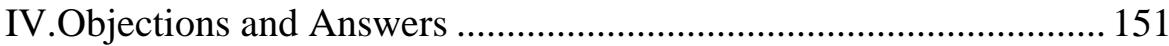

A. Objection: The Efficient System is Illegal, Immoral, or

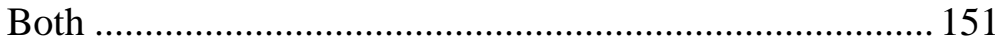

1. Is the Efficient System's Forced Work Component Illegal Involuntary Servitude Under the Thirteenth Amendment?

2. Is the Efficient System Immoral Because of its Similarities to Systems of Indentured Servitude and Slavery?

3. Is the Efficient System Immoral Because it Treats the Rich and Poor Differently?

4. Is the Efficient System Either Unconstitutional or Immoral Because it Amounts to Cruel and Unusual Punishment?

B. Objection: Prison is Necessary for Incapacitation .............. 163

C. Objection: Employers Will Not Hire Convicts

D. Objection: Bad Actors Will Not Work for Wages They Cannot Keep 


\section{INTRODUCTION}

This paper criticizes prison as a form of criminal punishment. Many such papers have been published in recent years, and many of them make worthy arguments, including that the staggering rate of incarceration in the United States is alarming, ${ }^{1}$ that our system of imprisonment is infected with racial and socioeconomic discrimination, ${ }^{2}$ that the privatization of our prisons leads to corruption, ${ }^{3}$ and that the conditions of American prisons are so brutal and inhumane as to be illegal. ${ }^{4}$ This paper takes a different approach. First, this paper relies exclusively on economic analysis - rather than social-justice or political analysis - to criticize imprisonment as a criminal punishment. Furthermore, while it draws descriptions and statistics from the aforementioned lines of inquiry, the goal of this paper is to question our system of imprisonment at a more fundamental level. Many other papers demand a better system of imprisonment, tacitly accepting that prison is an appropriate - or even inevitable — method for punishing criminals. By contrast, this paper questions whether, from an efficiency standpoint, it makes sense to imprison criminals at all.

Gary Becker's Crime and Punishment: An Economic Approach ${ }^{5}$ famously brought the tools of economics to bear on the criminal law. Judge Richard Posner's An Economic Theory of the Criminal Law ${ }^{6}$ introduced Becker's methods into the law review literature. Since the publication of both, law-and-economics scholars have, more or less, accepted prison as a fundamental tool of the criminal law. ${ }^{7}$ Such

1 See, e.g., Anne R. Traum, Mass Incarceration at Sentencing, 64 Hastings L.J. 423, 428 (2013).

2 See, e.g., Floyd D. Weatherspoon, The Mass Incarceration of African-American Males: A Return to Institutionalized Slavery, Oppression, and Disenfranchisement of Constitutional Rights, 13 TEX. WESLEYAN L. REV. 599, 605 (2007).

3 Ahmed A. White, Rule of Law and the Limits of Sovereignty: The Private Prison in Jurisprudential Perspective, 38 AM. CRIM. L. REV. 111, 113 (2001).

4 Olga Giller, Patriarchy on Lockdown: Deliberate Indifference and Male Prison Rape, 10 CARDOZO WOMEN's L.J. 659, 664 (2004).

5 Gary S. Becker, Crime and Punishment: An Economic Approach, 76 J. Pol. Econ. 169 (1968).

6 Richard Posner, An Economic Theory of the Criminal Law, 85 Colum. L. REV. 1193 (1985).

7 Here and throughout I present Posner's view in An Economic Theory of the Criminal Law as the established law-and-economics position. In doing so, I recognize that academics disagree with various positions that Posner takes. Here, as everywhere, the "standard" view is not the only view. Nonetheless, Posner's work stands as an incisive and widely-respected analysis of the criminal law. And, though others have 
theorists argue that the purposes of the criminal law are to minimize behavior that causes social losses and to do so efficiently. ${ }^{8}$ A primary method for minimizing such destructive behavior is deterrence. By increasing the private costs of bad actions, the law can reduce the expected private value of bad acts to or below zero, thereby disincentivizing their commission. ${ }^{9}$ Tort law can impose such private costs, but these costs are capped at the bad actor's - often limitedmaterial wealth. ${ }^{10}$ Thus, the argument goes, when optimal deterrence requires private costs in excess of those recoverable in tort law, criminal law steps in to impose further penalties, including imprisonment. ${ }^{11}$

Scholars of law and economics often simply assume that prison is the best criminal punishment for achieving optimal deterrence. ${ }^{12}$ Where they do not assume it, they mount only cursory arguments to that effect. ${ }^{13}$ But the conclusion is not obvious. An economically optimal criminal punishment ought not simply achieve optimal deterrence, it should do so at the lowest social cost. And nothing guarantees prison's cost advantage over alternative modes of punishment.

The reason these scholars have assumed the inevitability of prison is, to be sure, largely because of the nature of their projects. Scholars like Becker and Posner primarily wished to introduce economic thinking into the scholarly dialogue surrounding criminal law. In doing so, they focused on core concepts, rather than institutional examination. Indeed, no scholarly work has yet endeavored to combine the economic insights of Becker and Posner with a ground-up examination of the benefits and costs of our actual system of criminal punishment.

criticized it, no other work has comprehensively treated the inefficiencies of imprisonment presented herein. For another comprehensive treatment of the economic underpinnings of criminal law, see A. Mitchell Polinsky and Steven Shavell, The Economic Theory of Public Enforcement of Law, 38 J. ECON. LIT. 45 (2000).

8 See, e.g., Posner, supra note 6, at 1201-02.

9 See id.

10 See id. at 1203-05.

11 See id. at 1212-13.

12 See id.; Becker, supra note 5, at 196 (mentioning only prison and its conventional counterparts, probation and parole, as punishments available for deterring judgmentproof criminals). But see A. Mitchell Polinsky \& Paul N. Riskind, Deterrence and the Optimal Use of Prison, Parole, and Probation (Stanford Law \& Econ. Olin, Working Paper No. 507, 2017), https://papers.ssrn.com/sol3/papers.cfm?abstract_id=2968614 (analyzing the differential costs per unit of disutility for different sanctions).

13 See Posner, supra note 6, at 1212 (arguing that physical pain is a poor deterrent due to people's inability to prospectively imagine it and assuming that prison is, therefore, the apparent alternative). 
This paper seeks to fill that gap. In doing so, it systematically treats together four major costs of imprisonment as a mode of punishment. Once it has fully examined the costs of prison, this paper engages in a thought experiment. Relying exclusively on the principles of economic welfarism, it asks whether criminal punishments other than prison might achieve optimal deterrence at a lower social cost. It concludes that many other forms of criminal punishment could indeed do so.

The first major social cost of prison examined herein is administrative. As commentators regularly point out in other contexts, keeping a person in prison is extremely expensive. ${ }^{14}$ Prisoners must be humanely housed, fed, guarded, and provided with healthcare and recreation, all at significant cost to the public.

The second social cost of prison is inherent to the act of imprisonment itself: prison destroys the economic value of the prisoner. Prisoners generally do not work while they are in prison, and they certainly do not work in the mode of employment that maximizes the value of their labor. Thus, prisoners' lost earnings during years of imprisonment constitute a significant social loss. Furthermore, the stigma of prison itself may contribute to prisoners' long-term inability to find work, thus compounding the initial loss. Such losses do not only reduce aggregate social wealth; they also reduce the amount of wealth that victims can recover following a crime. Every dollar not generated by a criminal actor is one dollar that cannot be given to a victim as restitution for his or her suffering.

The third cost of prison comes in the form of significant perverse incentives. Because of its high administrative costs, the prison system generates substantial payments to parties other than the victims of crime. These parties' interests are not aligned with those of society as a whole; they benefit from high levels of crime and incarceration. Thus, parties that benefit from the prison system are incentivized to avert or delay reforms that would lead to a reduction in total incarceration.

The fourth cost arises because prison unnecessarily ties together multiple kinds of private costs. In doing so, it puts deterrence at crosspurposes with efficiency. When one attempts to optimize for social cost,

14 See The Price of Prisons: What Incarceration Costs Taxpayers, VERA INSTITUTE OF JUSTICE 10 (July 20, 2012),

http://www.vera.org/sites/default/files/resources/downloads/price-of-prisons-updatedversion-021914.pdf (estimating the national average cost at \$31,286). 
one deters suboptimally. And when one attempts to optimize for deterrence, social costs rise suboptimally.

Having examined these social costs of prison, this paper argues that they could be significantly reduced. Alternative systems of criminal punishment would be significantly less socially costly than the prison system. The annals of human history contain a stunning panoply of methods for imposing private costs on criminals. While prison necessarily destroys the prisoner's economic value by preventing him from working in his highest-value employment, other historicallycommon punishments impose no such cost. Neither flogging, nor pillory, ${ }^{15}$ nor tarring and feathering, nor any number of other ancient punishments necessarily prevents a bad actor from working in highvalue employment. Nor do more creative punishments invented by contemporary judges, including: forcing criminals to publicly carry embarrassing signs, ${ }^{16}$ mandating that they sleep in doghouses, ${ }^{17}$ or requiring them to undergo unwanted haircuts. ${ }^{18}$ Not only do such punishments preserve the bad actor's economic value, they also reduce administrative costs and perverse incentives as compared with imprisonment. Thus, significant social losses caused by the use of prison as punishment are, theoretically, avoidable.

In examining possible alternative modes of punishment, this paper construes its range of interests narrowly. The thought experiment performed herein asks whether the economic aims of optimal deterrence at minimal social cost are best served by imprisonment, or by some other system of punishment. In doing so, the experiment examines the economic merits of alternative punishments to prison. Some of these alternative punishments will doubtless strike readers as impermissible for various non-economic reasons. Certain punishments discussed herein may appear to readers as, alternatively, barbaric, degrading, reminiscent of darker periods in American history, or objectionable on other grounds.

15 Placement of the criminal in public stocks to invite public scorn.

16 See, e.g., United States v. Gementera, 379 F.3d 596 (9th Cir. 2004); see also Dan M. Kahan \& Eric Posner, Shaming White Collar Criminals: A Proposal for Reform of the Federal Sentencing Guidelines, 42 J.L. \& ECON. 365, 386 (1999).

17 See Texas Con To Do Time In Doghouse, The SMoking Gun (Feb. 25, 2003), http://www.thesmokinggun.com/documents/crime/texas-con-do-time-doghouse.

18 See Brittney R. Villalva, Judge Ponytail Sentence, Mother Forced to Cut Daughter's Hair as Punishment, THE CHRISTIAN POST (June 26, 2012), http://www.christianpost.com/news/judge-ponytail-sentence-mother-forced-to-cutdaughters-hair-as-punishment-video-77239/. 
Such arguments have significant merit, and this paper does not attempt to rebut them wholesale. It does, however, offer a response of a decidedly economic bent, asking whether the transition to some alternative system of punishment would be, on the margin worse than keeping the current system. That is, it asks whether our current system of imprisonment might be just as objectionable on non-economic grounds as any proposed alternative. If prison is just as barbaric, cruel, or degrading as the alternatives, then such criticisms do not strongly support one system over the other. Thus, such criticisms are best framed as objections to both our current system of imprisonment and its alternatives. If that is right, non-economic critiques rightly raise fundamental questions about the goals of the criminal law itself. It might well be the case that no system of criminal law grounded in punishment and deterrence can be, all things considered, morally justified. But such questions are beyond the scope of this paper.

This paper proceeds in four Parts. Part I details the standard lawand-economics view of the criminal law. It describes the kind of optimal deterrence that law-and-economics scholars believe the criminal law should attempt to achieve. It also characterizes various challenges to achieving such deterrence that are relevant to the project at hand. Part II then makes the case that prison is suboptimal as a punishment. This is primarily because prison fundamentally replaces private costs imposed via wealth transfers with private costs imposed via wealth destruction. Part III discusses an alternative to prison as punishment, describing the alternative's reduction in net social costs. Finally, Part IV considers objections to the proposed alternative. This paper argues that the alternative is legal and generally suitable for performing the same social functions as prison. It also grapples with the moral concerns raised by the alternative. While acknowledging these moral concerns as serious, it argues that they generally apply with similar force to both our current system of imprisonment and the proposed alternative.

\section{The LAW ANd ECONOMICS VIEW OF CRIMINAL LAW}

The standard law-and-economics view endorses prison as a means of imposing private costs on bad actors, thereby optimally deterring bad acts. The idea is simple, but its details can be somewhat more complex. And the details matter when analyzing the efficiency of a given form of criminal punishment. This section lays out the details of the standard law-and-economics analysis of the criminal law, including its widespread endorsement of prison as an efficient punishment. It 
focuses on three major goals of that analysis, including: achieving optimal deterrence, minimizing social costs, and avoiding perverse incentives. The considerations of this section are drawn, in large part, from Posner's An Economic Theory of the Criminal Law. ${ }^{19}$ That article, while over 30 years old, remains one of the most cited and respected economic analyses of the subject. ${ }^{20}$

\section{A. Optimal Deterrence}

Both criminal and tort law are designed to regulate bad acts. Specifically, according to economic thinking, they are designed to regulate behavior that would otherwise cause net social losses. We can tell that bad acts cause such losses because such behaviors almost always circumvent perfectly functional markets. ${ }^{21}$ Bad actors-burglars, fraudsters, murderers, and the like-take via pure coercion that for which they could have otherwise bargained. ${ }^{22}$ Markets with low transaction costs are, "virtually by definition, the most efficient method of allocating resources," because they allow parties to freely decline wealth-reducing transactions. ${ }^{23}$ Thus, the economic argument goes, both criminal and tort law seek to efficiently minimize such market-avoiding acts. $^{24}$

Without the law, bad acts would often have a positive expected value to those who committed them. This would create incentives favoring such acts. ${ }^{25}$ The law, then, seeks to eliminate such incentives and, instead, deter bad acts. Tort law does this by transferring wealth from the bad actor to his victim. How much wealth should tort law transfer in order to achieve its goal? At first blush, it might seem that tort law need only transfer an amount greater than the bad actor's naïve expected valuation of the bad act. ${ }^{26}$ To adapt an example of Posner's, imagine a jewel thief who plans to steal another person's jewel valued at $\$ 10,000$. Assuming that the theft of the jewel is costless and certain to succeed, the thief values his potential burglary at $\$ 10,000$. If the law

19 See Posner, supra note 6, at 1193.

20 Citing references to An Economic Theory of the Criminal Law, WESTLAw, https://1.next.westlaw.com (search 85 Colum. L. Rev. 1193; then access citing references) (last visited Nov. 5, 2017).

21 See Posner, supra note 6, at 1195-1201.

22 Id. at 1196.

23 Id. at 1195.

24 Id. at 1201-05.

25 Id. at 1201-02.

26 Id. at $1206-07$. 
turns and imposes $\$ 11,000$ in tort liability on the thief, then his bad act is disincentivized. ${ }^{27}$

In real life, an $\$ 11,000$ tort penalty is unlikely to be optimal. The above example ignores the fact that not every thief can be detected and prosecuted. ${ }^{28}$ Assume that there is only a 50\% chance that the thief will be caught and held liable in tort. Then, the expected tort liability in the above example is only $\$ 5,500$ - far less than the thief's valuation of the jewel - and the theft is not deterred. However, if the tort penalty were set at $\$ 22,000$ with a $50 \%$ rate of liability, the expected liability rises again to $\$ 11,000$, and deterrence is restored. A $10 \%$ rate of liability would require damages in the amount of $\$ 110,000$. Thus, the right penalty for optimal deterrence will often be quite high, as compared with the coercive value transfer at issue in a given bad act. ${ }^{29}$

This fact - the high penalties necessary for optimal deterrencegives rise to the standard law and economics rationale for the criminal law. Tort law can theoretically impose, via a combination of actual and punitive damages, unlimited liability for the purpose of achieving optimal deterrence. But at some point, a bad actor's ability to pay runs out. Where a bad actor is judgment-proof, any tort liability beyond his ability to pay cannot act as a deterrent. ${ }^{30}$ One cannot, as the saying goes, wring blood from a stone. Suppose the aforementioned jewel thief has a net worth of only $\$ 50,000$, the rate of detection and punishment is $10 \%$, and the sanction necessary for deterrence is therefore $\$ 110,000$. In one tenth of all cases, the thief will be caught and have $\$ 110,000$ in tort liability leveled at him. But he will only actually pay $\$ 50,000$. The expected private cost of the theft is only $\$ 5,000$, and the theft is undeterred. This is where the criminal law steps in.

The criminal law can impose "nonmonetary sanctions" on bad actors. ${ }^{31}$ These are costs that the bad actors bear via means other than monetary transfers. Nonmonetary sanctions include, for example, imprisonment, pillory, flogging, and execution. ${ }^{32}$ When a bad actor would otherwise be judgment-proof, nonmonetary sanctions can be used to fill the gap between the reduced expected cost of a bad act and the

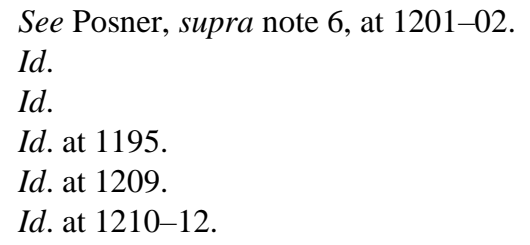


cost at which the actor would actually be deterred. ${ }^{33}$ Imagine again the jewel thief worth $\$ 50,000$ who is $10 \%$ likely to be caught and fined $\$ 110,000$. Without nonmonetary sanctions, the expected cost of the theft is only $\$ 5,000$. But if the criminal law can impose an additional $\$ 60,000$ worth of nonmonetary sanctions on the jewel thief then the total expected punishment is again raised to $\$ 11,000$. Deterrence is thus restored.

So far, the standard view has shown that the right level of punishment for bad acts is often much higher than the value transferred by the act itself. It has also shown that the criminal law can impose nonmonetary sanctions, restoring optimal deterrence even against judgment-proof actors. Taken together, these discoveries might seem to imply that there should be no cap on the criminal penalty imposed for a bad act. After all, if bad acts are deterred when the expected costs to bad actors exceed expected benefits, then astronomical costs should deter all crimes. ${ }^{34}$

Some societies have, at some point in history, taken such an approach: in medieval England, the punishment for essentially every crime was death. ${ }^{35}$ But these methods carry significant disadvantages. Principally, a regime under which every crime is punishable by death is a regime under which there can be no marginal deterrence. In such a world, once a criminal has, for example, robbed someone, he might as well kill that person, thereby eliminating a witness. $^{36}$ The additional, more serious crime will not increase his potential punishment.

Optimal deterrence does not simply mean setting the penalties correctly to deter each particular crime. Rather, the system of deterrence must be coherent, minimizing the overall social losses from bad actions. As such, optimally deterrent penalties cannot be calculated narrowly, considering only the expected value of a single crime. They must consider how to best penalize the whole range of bad acts in which a bad actor might engage. The penalties for less-harmful bad acts should be lower than those for the most serious ones.

33 See Posner, supra note 6, at 1195.

34 Even better, one might imagine, higher penalties achieve optimal deterrence at a lower rate of detection and punishment. Insofar as detection and punishment are costly, higher penalties lower costs.

35 Sean McGlynn, Violence and the Law in Medieval England, HISTORY TODAY (Mar. 24, 2016), http://www.historytoday.com/sean-mcglynn/violence-and-law-medievalengland (describing the overuse of execution, including to punish a theft of four pence).

36 See Posner, supra note 6, at 1207. 
The standard law and economics account of optimal deterrence, then, teaches three lessons. First, the punishment necessary for optimal deterrence is usually much higher than the value coercively transferred by the bad act. This is because imperfect detection renders the expected costs of bad acts lower than the actual costs imposed upon detection and prosecution. Second, tort law alone cannot impose optimal sanctions. When the optimal sanction exceeds the bad actor's ability to pay, the bad actor is under deterred. This is why the criminal law must step in, using nonmonetary sanctions to fill the gap between ability to pay and optimal sanctions. Finally, even though nonmonetary sanctions vastly raise the theoretical cap on deterrent costs that can be imposed on bad actors, astronomical punishments are inefficient. This is because such punishments eliminate marginal deterrence. Thus, optimal deterrence requires punishments that are neither too low nor too high, but just right.

\section{B. Social Costs}

So far, this Part has primarily discussed the law and economics view of the interplay between criminal law and private costs. Criminal law strives to impose private costs upon bad actors to optimally deter bad action. But the economic analysis of law is also-perhaps principally-concerned with social costs. The distinction between the two is just this: private costs are borne by an individual while not necessarily decreasing overall societal wealth, while social costs are those that $d o$ decrease societal wealth. The point of optimal deterrence is the imposition of private costs to reduce social costs - namely bad acts. But bad acts are just one socially costly phenomena that the criminal law ought to avoid.

Enforcement of the law itself generates social costs. There are obvious ones, like the costs of investigating crimes, bringing tort suits, or paying judges and lawyers and bailiffs. ${ }^{37}$ The administration of penalties, too, is a significant social cost. For example, in 2012, the estimated average cost to incarcerate a single American prisoner for a year was $\$ 31,286$. $^{38}$

There are also nonobvious social costs. Nonmonetary sanctions, by their very design, necessarily decrease societal wealth. Jeremy Bentham recognized this point, observing that "all punishment is

37 For example, the annual budget of the Federal Bureau of Investigation in 2016 was $\$ 8.7$ billion. Quick Facts, FEDERAL BurEaU OF InVESTIGATION (Feb. 21, 2016), https://www.fbi.gov/about-us/quick-facts/quickfacts.

38 The Price of Prisons: What Incarceration Costs Taxpayers, supra note 14. 
mischief: all punishment in itself is evil. Upon the principle of utility, if it ought at all to be admitted, it ought only to be admitted in as far as it promises to exclude some greater evil." 39 The whole point of nonmonetary sanctions is that they make the sanctioned person worse off. They do so by destroying the bad actor's nonmonetary wealth. Insofar as nonmonetary sanctions engender no corresponding increase in someone else's wealth, their costs are not merely private, but also social.

Destroying wealth is the only way that nonmonetary sanctions can serve as deterrents. For a sanction to be effective, it must deprive the sanctioned party of something. When sanctions take the form of fines or tort damages, they deprive the sanctioned party by transferring liquid wealth to another party. Cash, property, and other goods readily converted into money are taken from the bad actor and given to the victim or the government. The bad actor's wealth is reduced, but the transferee's wealth increases. Ignoring incidental costs-including the costs of making the transfer and possible effects of money's diminishing marginal utility - the aggregate amount of societal wealth remains constant.

Nonmonetary sanctions ideally step in when the bad actor has no more transferrable wealth to give. They then impose further private costs by destroying the bad actor's nonmonetary wealth. A bad actor's freedom of movement cannot be transferred, but can be destroyed via imprisonment. The same goes for wealth in the form of bodily integrity, free association, and a whole array of other endowments stripped away by nonmonetary sanctions. Because the only way to create private costs of this kind is to destroy wealth, such private costs are also, necessarily, social costs. That is to say, when such private costs are imposed, the aggregate wealth of society is reduced. Interestingly, leading scholars of law and economics tend to underestimate or undertheorize these longrecognized costs. ${ }^{40}$

There are at least two kinds of social costs associated with the

39 JEREMY BENTHAM, AN INTRODUCTION TO THE PRINCIPLES OF MORALS AND LEGISLATION 26 (2003).

40 See Posner, supra note 6, 1205-14 (attending to the relatively small destructions of wealth caused by high fines, but ignoring the astronomical losses caused by, e.g. executions); See also Gary Becker, Crime and Punishment: An Economic Approach, 76 J. OF POLITICAL ECON. 169, 193 (1968) (theorizing lost wages while in prison primarily as a private cost to prisoners and mentioning them only in passing during a discussion of social costs); But see JOHN BRONSTEEN, CHRISTOPHER BUCCAFUSCO \& JONATHAN S. MASUR, HAPPINESS AND THE LAW 95-117 (2015) (discussing punishments imposed on criminals as both private and social costs). 
enforcement of criminal law. Some are administrative, including the costs of discovering bad acts, prosecuting them, and administering sanctions. Some are inherent. Monetary sanctions carry few or no inherent social costs, ${ }^{41}$ because they merely transfer wealth. However, nonmonetary sanctions, by their very nature, destroy private wealth without corresponding gains elsewhere. They therefore necessarily reduce total societal wealth. An economic view of the criminal law should be attentive to both kinds of social costs. It should advocate for a system that strives to minimize total social losses, including both those associated with bad acts themselves and also those associated with deterring them. ${ }^{42}$

\section{Perverse Incentives}

Another piece of the economic puzzle when evaluating the criminal law is avoiding perverse incentives. A perverse incentive arises when someone benefits from activities that are, on the whole, undesirable. Such incentives invite social costs, insofar as they give people reasons to engage in antisocial behavior. How might a system of criminal law create such incentives? First, compare criminal punishment with tort liability.

In tort law, the party who recovers for an injury is the one who was actually harmed. If the victim can only recover in the amount of the actual harm, then he has no incentive to put himself in the path of a possible tort. What happens if the victim can recover vastly more than the amount of the actual harm? This might happen if punitive damages are available for the tort in question. As discussed above, the penalty required for optimal deterrence is often much higher than the value of the harm, and punitive tort damages can help fill the gap between the two. ${ }^{43}$ However, when a victim can recover much more for a tort than the harm he has suffered, an incentive arises for him to invite torts. Tort law can, to some extent, mitigate this effect by limiting recovery in cases of comparative or contributory negligence.

What if, instead of tort payments, the criminal law imposes a

41 The inherent social costs of monetary sanctions are not always zero. As Posner points out, monetary sanctions impose some private costs that do not correspond to any gains. For example, the use of large fines imposes a disutility on risk-averse actors without a corresponding gain to the recipient of the fine. See Posner, supra note 6, at 1207-08.

42 See id. at 1212-13 (discussing the social costs of criminal punishments).

43 See infra Part I.A. 
fine on some bad actor? Suppose that the fine is paid to someone other than the victim. Then someone benefits from bad acts without bearing the loss of harm. If the recipient of the fine is a single person, it is in his interest to place victims in the path of the very kinds of harm that the law attempts to minimize. A perverse incentive, indeed. What if the recipient is not a single person, but a local, state, or federal agency? Certainly, then, the perverse incentive is mitigated by its dissipation among many individuals. But if revenues from fines are essential for keeping the lights on and the employees employed, the agency may retain a real incentive to ensure that others are subject to bad acts. ${ }^{44}$

Non-monetary sanctions can give to perverse incentives similar to those associated with fines. For example, when a criminal is imprisoned, he pays no fine directly to his jailer. The relevant government, however, does pay the prison for its services. Thus, those who run, are employed by, or who benefit in any other way from the running of the prison have an incentive to keep cells full. Such incentives are powerful enough to corrupt at least some government officials. For example, in 2009, two Pennsylvania judges were found to have taken bribes from the operators of private prisons in exchange for rejecting the leniency pleas of hundreds of juvenile offenders. ${ }^{45}$ This problem is not isolated to imprisonment. Any nonmonetary sanction must be administered. As such, administrators of such sanctions will always be subject to perverse incentives regarding the bad acts for which they administer punishment.

At first blush, then, perverse incentives might appear inescapable in the endeavor of reducing bad acts. Any sanction aside from payment directly to the victim precisely equaling the amount of harm of the bad act creates a perverse incentive somewhere. But perverse incentives admit of degrees. In some cases, incentives may be larger, affect more people, or be more readily acted upon. Thus, an economically efficient system of criminal law should aim for the smallest, narrowest, and hardest to act upon perverse incentives when it selects its nonmonetary sanctions.

\section{Why Prison is Inefficient}

Prison performs poorly with regard to all of the above-discussed

44 For now, the feasibility of an agency's causing bad acts in order to profit is held aside. It is enough, for the moment, to note that such incentives exist.

45 Lucas Anderson, Kicking the National Habit: The Legal and Policy Arguments for Abolishing Private Prison Contracts, 39 PUB. CONT. L.J. 113, 128 (2009). 
economic goals of criminal punishment. First and foremost, imprisonment — especially as currently employed in America - produces massive social costs. These costs are both administrative and inherent. It is extremely expensive to keep people in prison and, when we do so, we destroy enormous amounts of social wealth in the form of prospective income. Second, prison creates significant perverse incentives. Because prison is expensive to administer, the prison system puts significant wealth up for grabs by those other than the victims of bad acts. This creates substantial incentives to ensure that the rate of imprisonment remains high. Finally, prison is a clumsy tool for achieving optimal deterrence. This is because it unnecessarily bundles together various kinds of nonmonetary sanctions. Prison imposes private costs on bad actors by: destroying their wealth, inhibiting their freedom of movement, inhibiting their freedom of interaction, creating psychological pressures, and many others. In striving for optimal deterrence at the lowest social cost, it will often be desirable to impose some, but not all, of these private costs simultaneously. Prison thwarts such attempts.

\section{A. Prison's Social Costs}

As discussed in Part I.B, all forms of nonmonetary criminal punishment entail social costs. Some of these costs are administrative and some are inherent to the sanctions themselves. What is not common to all forms of criminal punishment is the magnitude of such social costs. And the magnitude of prison's social costs is great.

\section{Administrative Costs}

Start with the obvious administrative costs of imprisonment. Recent estimates of the average cost to imprison a single inmate in the United States for one year put the figure above $\$ 30,000 .{ }^{46}$ In some states, like California and Washington, the cost can creep above $\$ 40,000 .{ }^{47}$ In Connecticut, the average is $\$ 50,262 .{ }^{48}$ New York takes the

46 See Melissa A. Knopp, Breaking the Cycle: Ohio Reentry Courts, 41 OHIO N.U.L. REv. 737, 740 (2015) (citing Annual Determination of Average Cost of Incarceration, 80 FED. REg. 12523-01 (Mar. 10, 2015)). The average annual cost for 2014 was $\$ 30,619.85$.

47 See The Price of Prisons: What Incarceration Costs Taxpayers, supra note 14, at 10; see also Cole F. Heyer, Comparing the Strike Zones of "Three Strikes and You're Out" Laws for California and Georgia, the Nation's Two Heaviest Hitters, 45 SUFFOLK U. L. ReV. 1217, 1235 (2012).

48 See The Price of Prisons: What Incarceration Costs Taxpayers, supra note 14, at 
prize for the state in which it is most expensive to hold a prisoner, coming in at a whopping average cost of $\$ 60,076 .{ }^{49}$ These are not estimates of the average total cost to the state of punishing a prisoner; they include only costs directly connected with imprisonment itself. These costs are those billed directly from departments of corrections, along with other closely related costs like employee benefits and prisoner services. ${ }^{50}$ They do not include, for example, costs of policing, trials, appeals, or post-conviction collateral attacks. Thus, these numbers are a mere sample of what prison costs to administer.

A recent estimate from the World Bank puts the American GDP per capita somewhere between $\$ 49,000$ and $\$ 55,000 .^{51}$ Thus, the national average administrative cost of imprisoning one American prisoner approaches $60 \%$ of GDP per capita. This figure is astonishing.

Of course, it is unfair to count every dollar of the administrative costs of imprisonment as a net social loss. At least some such costs would be necessary whether a given criminal was imprisoned, punished in some other way, or not punished at all. For example, humans need to eat whether they are imprisoned or free. They also need shelter, water, clothing, and a whole host of basic goods in order to survive. Thus, a fairer estimate of the administrative social costs that prison entails would subtract such expenditures from the total cost figures above. Such detailed itemization of prison budgets is beyond the scope of this paper. The goal here is merely to demonstrate that prison is less efficient than plausible alternatives, not to work up a precise estimate of total losses due to prison's inefficiencies. However, it is worth noting that, even once such unavoidable costs are deducted from the prison bill, costs are still likely to be substantial. Consider that it is these very life-sustaining costs that prisons themselves seek to minimize. For example, various sources estimate the cost of feeding an average prisoner to be between just $\$ 1.75$ and $\$ 2.65$ per day. ${ }^{52}$ Nor do prisons make significant expenditures on lavish accommodations, expensive personal hygiene

10.

49 Id.

$50 \quad I d$ at $* 2-6$.

51 GDP per capita (current US\$), WORLD BANK, http://data.worldbank.org/indicator/NY.GDP.PCAP.CD?order=wbapi_data_value_2011 +wbapi_data_value+wbapi_data_value-first\&sort=desc.

52 See Prisoners Pay the Price of Food Cost Increase, PRIson Legal News (Mar. 21, 2016), https://www.prisonlegalnews.org/news/2013/aug/15/prisoners-pay-the-price-offood-cost-increases; Peter Wagner, The Prison Index, PRISON POLICY InITIATIVE (2003). 
supplies, or designer clothing. As Cook County Sherriff Tom Dart has put it, prison "is not the Four Seasons." ${ }^{\text {"53 }}$ Thus, the most significant expenditures of imprisonment are likely to be on the necessities of incarceration - secure cells, guards, surveillance, etc.-rather than on the necessities of life. Even ignoring unavoidable expenditures, then, the administrative social costs of prison are enormous.

\section{Inherent Costs}

The administrative social costs of imprisonment are welldocumented and well-understood. This is not surprising. When money is spent to administer imprisonment, that money flows to people like prison guards, private prison operators, food vendors, and utilities companies. That is to say, such expenditures generate invoices. Invoices have to be paid by someone; in this case, the government. And, in turn, the government raises money to pay such bills by levying taxes, which are paid by the general public. Administrative costs are highly visible because someone has to reach into his wallet and fork over the cash.

The inherent social costs of imprisonment are, by contrast, more or less invisible. That is because they do not, like administrative social costs, take the form of monetary transfers from one party to another. Rather, the inherent social costs of prison are largely composed of wealth that would have been created, but, because of prison, was not. This kind of wealth destruction does not generate invoices. It does not require governments to write checks or to tax citizens. Because of this, such costs are likely to be ignored by both scholars and politicians.

Prison needlessly prevents bad actors from earning money. Indeed, the wages bad actors must forego while in prison count among prison's deterrent private costs. But, in imposing this private cost, prison destroys societal wealth that otherwise have been transferrable to victims or the government. Every dollar not earned by a prisoner is a dollar not added to the size of the total social pie. Prison replaces nonmonetary sanctions in the form of socially costless wealth transfers with those in the form of socially costly wealth destruction.

To fully illustrate the inherent social costs of imprisonment, it is helpful to draw an analogy outside of the criminal law. As discussed in

53 Jeff Ruby, Dining Critic Tries Nutraloaf, the Prison Food for Misbehaving Inmates, Chicago MagazINE (Aug. 26, 2010), http://www.chicagomag.com/ChicagoMagazine/September-2010/Dining-Critic-Tries-Nutraloaf-the-Prison-Food-forMisbehaving-Inmates/. 
Part I.A., a primary function of the criminal law is to step in and impose private costs on bad actors when the optimally-deterrent level of punishment exceeds the bad actor's ability to pay. One might think of bad actors as debtors of a sort: because of their bad acts, they owe some amount of wealth. Indeed, bad actors are often literally debtors, since the value they must forfeit consists of monetary fines or tort damages.

If bad actors are like debtors, then judgment-proof bad actors are like insolvent debtors. They do not have enough (monetary) resources to pay their debts. Recall the jewel thief from Part I.A. If the thief steals a jewel worth $\$ 10,000$, and such thieves are held accountable for their bad acts only $10 \%$ of the time, the thief will only be deterred if, once he is caught, more than $\$ 100,000$ in private costs are imposed upon him. We can imagine such a thief who is caught, but whose lifetime potential assets are presently valued at only $\$ 50,000$. That is to say, with regard to the $\$ 100,000+$ debt he has incurred, he is insolvent.

Another area of the law that deals with insolvent debtors is bankruptcy. How, generally speaking, would bankruptcy law handle such an insolvent debtor? The specifics of personal bankruptcy are complex and unimportant here. What does matter is that a great swath of bankruptcy law is designed to maximize the value of the bankrupt estate, ensuring that there is as much wealth available to repay various debtors as is possible. The automatic stay, ${ }^{54}$ bankruptcy's bidding procedures, ${ }^{55}$ its thresholds for case dismissal, ${ }^{56}$ and many other provisions ${ }^{57}$ aim to ensure that, when a debtor owes more than he can pay, creditors as a whole are able to collect the maximum amount possible. One primary concern of bankruptcy is that disorderly collection by various creditors will destroy portions of an estate's value by, for example, ripping apart assets that would be much more valuable if kept together. ${ }^{58}$ By installing rules to avoid such outcomes, bankruptcy law aims to avoid the social

54 See Bryan G. Faubus, Narrowing the Bankruptcy Safe Harbor for Derivatives to Combat Systemic Risk, 59 DuKE L.J. 801, 828 (2010).

55 See Rachael M. Jackson, Responding to Threats of Bankruptcy Abuse in A PostEnron World: Trusting the Bankruptcy Judge as the Guardian of Debtor Estates, 2005 Colum. Bus. L. REV. 451, 508 n. 249 (2005).

56 See Geoffrey K. McDonald, Why "Litigation Tactic” is Not Cause for Dismissal of a Bankruptcy Case Under Section 1112(b), 20 J. BANKR. L. \& PRAC. 6 (2011).

57 See Rutheford B. Campbell, Jr. \& Christopher W. Frost, Managers' Fiduciary Duties in Financially Distressed Corporations: Chaos in Delaware (and Elsewhere), 32 J. CORP. L. 491, 511 (2007) ("The duty to maximize the value of the estate is built into the structure and purpose of the bankruptcy process.").

58 See Faubus, supra note 54, at 828. 
costs of wealth destruction.

This goal of wealth maximization in the face of insolvency is eminently sensible. When the value of the bankrupt estate is maximized, everyone-including the creditors and society as a whole-benefits. Thus, no matter what else bankruptcy law would say about the jewel thief, it would certainly have at least one goal: ensuring that the prisoner's transferrable wealth is maximized such that he can monetarily repay as much of his debt as possible. This, in turn, minimizes the amount of wealth-destroying nonmonetary sanctions necessary to achieve optimal deterrence.

Our current criminal law does just the opposite. Assume that the jewel thief's net worth in the above calculation includes the net present value of all of his future earnings. If he were not imprisoned, and 100\% of his lifetime monetary worth were transferred via monetary penalties to his victim or the government, he would be able to repay $\$ 50,000$. This would be roughly half of the debt he incurred because of his bad act. However, as soon as the thief is put into prison, his net present worth plummets. While in prison, he can earn no income. If most of the thief's $\$ 50,000$ present worth comes from expected earnings, and his prison sentence ensures that he is locked up for the rest of his working life, then his net present worth may fall to nearly $\$ 0$. In that case, he will be able to repay none of his debt by transferring money. His entire punishment will instead consist of wealth-destroying nonmonetary sanctions. In this way, our criminal law, unlike our bankruptcy law, actively works to destroy social value.

This reduction in bad actors' net present worth is a detriment to his "creditors" - tort claimants and governments to whom he owes fines - insofar as it reduces their recovery. But, more importantly, it is a huge social cost. Wealth transfers like tort judgments and fines are nearly socially costless. ${ }^{59}$ If the jewel thief pays his entire $\$ 50,000$ net worth to his victim, his wealth is reduced by that amount, but his victim's wealth increased by the same. Thus, holding aside administrative and transaction costs, overall societal wealth is unchanged. Our prison system fundamentally replaces socially costless wealth transfers with social losses. ${ }^{60}$ Instead of allowing the thief to earn

59 See Posner, supra note 6, at 1214.

60 This is, of course, not perfectly accurate. While wealth transfers themselves are essentially costless, the systems required to implement them-tort, administrative, or criminal proceedings - are costly. However, given the necessity of some legal system to impose deterrence on bad actors, such costs are unavoidable. Thus, holding constant the 
his $\$ 50,000$ and then punishing him by transferring it, the prison system immediately punishes him by destroying the $\$ 50,000$. From the thief's perspective, the two are essentially the same; he loses $\$ 50,000$ either way. But from society's perspective, the second is much worse. In the latter scenario, the world is $\$ 50,000$ poorer than it might have been.

As discussed in Part I.A., nonmonetary punishment is necessary wherever bad actors have too little money to pay the amount optimal deterrence demands. Furthermore, as discussed in the same section, all nonmonetary punishments create net social losses. That is their entire function. If all of a bad actor's wealth that can be transferred has been transferred, but his debt is not yet repaid, nonmonetary sanctions step in to destroy his non-transferrable wealth. Thus, insofar as optimal deterrence requires nonmonetary sanctions, it also requires social losses.

But our system of imprisonment imposes needless social losses. Optimally, nonmonetary sanctions step in to fill a gap between the bad actor's maximum transferrable wealth and the private costs necessary for deterrence. In other words, an efficient system of deterrence first maximizes the bad actor's monetary wealth, second transfers as much of it as possible without cost, and only then destroys wealth via nonmonetary sanctions. Our prison system, by contrast, jumps straight to nonmonetary sanctions, throwing criminals into prison shortly following their conviction. In doing so, our system prevents the creation of significant monetary value.

Let us frame these inherent social costs in terms of actual dollars. According to the U.S. Census Bureau, the per capita income of an American between March 2015 and March 2016 was \$28,555. ${ }^{61}$ There are obvious problems with using per capita income as a precise measure of the wages lost while in prison. For example, those sent to prison might, on average, earn less than the general population. But the figure is good enough for a rough estimate. The idea here is to get a sense of scale, not to calculate precise dollar figures. Using the per capita income figure, a 10-year prison sentence of a working-age person precipitates an inherent social cost of around $\$ 300,000$. That is, $\$ 300,000$ in value fails to be created. Taking another perspective, in 2013, there were 2.2 million people incarcerated in the United States. ${ }^{62}$

administrative costs of determining liabilities and the consequences thereof, wealth transfers can be treated as costless, when compared with other possible sanctions.

61 Quick Facts, U.S. CENSUS BUREAU, http://www.census.gov/quickfacts/table/INC910214/00 (last visited Mar. 21, 2016).

62 Incarceration, THE SENTENCING PROJECT, 
If those people had been in the workforce, the per capita income figure suggests that they would have earned over $\$ 60$ billion in wages in that year alone! But because they were imprisoned, rather than subjected to more efficient nonmonetary sanctions, those wages were lost. These are back-of-the-envelope figures ${ }^{63}$ but there can be no doubt that the social costs of imprisonment from lost wages during incarceration are staggering.

Prison's needless social costs do not end when convicts' sentences do. It is well established that imprisonment causes ex-convicts to face dismal odds of post-release employment. For example, a 2001 survey of employers in Los Angeles County found that "over 40 percent of employers indicated that they would 'probably' or 'definitely' not be willing to hire an applicant with a criminal record for a job not requiring a college degree." ${ }^{64}$ The problem has become sufficiently well recognized that a number of states have instituted "ban the box" laws. ${ }^{65}$ Those laws make it illegal for employers to ask about past convictions on job application forms. ${ }^{66}$ Thus, imposing prison as an immediate nonmonetary punishment for bad acts causes a net social loss of the bad actor's wages not only while incarcerated, but also for years thereafter. ${ }^{67}$ One study suggests that these losses amount to an annual loss in output of between $\$ 57$ and $\$ 65$ billion. ${ }^{68}$

http://www.sentencingproject.org/template/page.cfm?id=107 (last visited Mar. 21, 2016).

63 These are very rough estimates, and it is not difficult to find fault with them. For example, it may well be that the economy could not absorb an additional 2.2 million workers, were all prisoners set free. It is also likely that those who are sent to prison are, on average, poorer than the general population. Perhaps a substantial number of prisoners were unemployed prior to imprisonment. These are all fair points. My goal here is merely to create a rough sense of scale.

64 Nancy B. Sasser, “Don't Ask, Don't Tell:” Negligent Hiring Law in Virginia and the Necessity of Legislation to Protect Ex-Convicts from Employment Discrimination, 41 U. Rich. L. REV. 1063, 1065 (2007) (citing Harry J. Holzer, Steven Raphael, \& Michael A. Stoll, How Willing are Employers to Hire Ex-Offenders?, Focus, at 40, 41 (Summer 2004) http://www.irp.wisc.edu/publications/focus/pdfs/foc232h.pdf.).

65 See Rachel Santitoro, Banning the Box in New Jersey: A Small Step Toward Ending Discrimination Against Ex-Offenders, 13 RUTGERs J. L. \& PUB. POL'Y 215 (2015).

66 Id. at 215-16.

67 It is a fair objection that convicts' difficulty finding work is not obviously caused by imprisonment itself. It could, instead, be a result of their conviction, no matter the punishment. This point is taken up below in Part IV.C.

68 John Schmidt \& Kris Warner, Ex-offenders and the Labor Market, CTR. FOR ECON. \& POL'Y RES. 1 (2010), http://cepr.net/documents/publications/ex-offenders-201011.pdf. 
It gets worse. Prison is a place where lots of bad actors are placed, given enormous amounts of free time, and forced to spend that time together. For those prisoners who are already seriously committed to a life of crime, prison is a great place to network. ${ }^{69}$ For those who are not, it is a great place to get serious. Perhaps that is why longer prison sentences appear to cause increases in recidivism among those incarcerated. $^{70}$ If sending bad actors to prison does increase the likelihood that they will commit further bad acts, the social costs are twofold. The first-order losses come in the form of increased bad acts themselves. Once bad acts increase, more people are sent back to prison, and society bears additional second-order costs of the very kinds described in this section.

Prison's inherent social costs are insidious because of their invisibility. Because they largely take the form of unearned income, no one must take conscious action to pay them. But they exist, all the same. Our system of imposing prison as a nonmonetary sanction immediately after conviction destroys significant societal wealth. If prison were not so imposed, bad actors could earn wages and transfer those wages to the victims or the government. But prison prevents bad actors from earning wages. It thus prevents victims from recovering fully and, more significantly, it impoverishes society as a whole. Nor do these costs end when the prisoner is released. Convicts have a difficult time finding work following their release from prison. Prison also increases the probability of additional crimes. In these ways, our system of imprisonment heaps social cost upon social cost.

\section{B. Prison's Perverse Incentives}

As discussed above, perverse incentives arise whenever someone can privately benefit from an occurrence that is socially

69 See generally Bayer, Patrick Bayer, Rani Hjalmarsson \& David Pozen, Building Criminal Capital Behind Bars: Peer Effects in Juvenile Corrections, 124 Q. J. OF ECON. 105 (2009).

70 See John "Evan" Gibbs, Jurisprudential Juxtaposition: Application of Graham v. Florida to Adult Sentences, 38 FlA. ST. U. L. REV. 957, 975 (2011); Max Hellman, Barber v. Thomas: The Supreme Court's Interpretation of the Federal "Good Time Credits" Is Undermining Sentencing Reform, 42 MCGEORGE L. REV. 873, 896 (2011). But see Johanna E. Marking, Federal Crime and Punishment Meet the New System, Same As the Old System?, 61 FED. LAw. 65, 69 (2014) ("A 1994 U.S. Department of Justice study states 'The great majority of recidivism studies of State prison releasees and all studies of Federal prison releasees report that the amount of time inmates serve in prison does not increase or decrease the likelihood of recidivism."'). 
detrimental. This will often be the case when the criminal law seeks optimal deterrence. The private costs necessary for optimal deterrence are often greater than the bad actor's actual gain from a given bad act. Thus, one of three things can happen. First, the state could impose private costs on the bad actor in an amount equal to the victim's loss. Such costs could take the form of wealth transfers directly to the victim. In this case, there are no perverse incentives because no one benefits from the bad act. ${ }^{71}$ But the bad act is under deterred since the rate of liability for it is likely to be less than $100 \%$. Second, the state could impose optimally deterrent private costs in the form of wealth transfers from the bad actor to the victim or the government. In this case, optimal deterrence is achieved, but whoever gets paid an amount greater than his personal harm gains a perverse incentive. It is to those parties' advantage to ensure as many bad acts occur and are prosecuted as possible. Or, at the very least, such parties lack any incentive to prevent bad acts.

The third option is the one that looks most like our current system of imprisonment. In this scenario, monetary transfers play a minor role in the scheme of sanctions, with nonmonetary sanctions taking the major role. When a bad actor is imprisoned, monetary sanctions cannot be substantial because prison destroys much of the bad actor's available wealth. One could idealize our criminal justice system, imagining that monetary payments were intentionally made only in the amount of the actual harm of the bad act, and nonmonetary sanctions (prison) then step in to achieve optimal deterrence. Under such a scheme, there at first appear to be no perverse incentives at play; no one can get paid more than his private costs. Of course, substituting socially costless wealth transfers with socially costly wealth destruction can be economically disastrous. This seriously undermines the viability of the third option.

Worse, the third option does not actually eliminate perverse incentives. All systems of nonmonetary sanction require administration. As described above, ${ }^{72}$ administration requires administrators who privately benefit from others' woes. Prison guards, penal service companies, executioners, and parole officers are all better off when

71 Assuming that the bad actor's gain is less than the victim's loss. This is likely to be the case in many situations. If one actor values some action more than another actor disvalues it, the parties will generally be able to bargain such that the action occurs with mutual consent. In this case, it is less likely that anything illegal will occur.

72 See supra Part I.C. 
crime and incarceration rates are high. If rates fall, these parties are out of a job. Thus, the perverse incentives associated with nonmonetary sanctions spring from administrative costs rather than costs directly borne by bad actors.

What does this mean? If every method of punishing bad actors entails either perverse incentives or under deterrence, is the situation hopeless? Under deterrence and perverse incentives are simply social costs, and costs admit degrees. The goal, then, of an economically sound system of criminal justice should be to minimize these costs.

How does our current system of imprisonment fare with regard to the cost of perverse incentives? There are two ways in which such incentives might be analyzed: by their magnitude and by their loci. On both views, our system fares poorly.

Perverse incentives, as a general rule, become worse as they become bigger. A small perverse incentive might not be worth pursuing. The costs of achieving the perverse end might outweigh the benefits. Alternatively, countervailing interests - like private commitments to achieving a just, orderly society - can more easily overwhelm small perverse incentives than large ones. As such, systems of punishment that create small perverse incentives should, as a rule, be better than those that create large ones.

Recall that, for nonmonetary punishments, perverse incentives are held by administrators, so they are closely tied to administrative costs. Further recall that imprisonment entails monumental administrative costs. An average of $\$ 31,286$ per prisoner per year is disbursed to entities in commercial affiliation with the prison system. Multiply that by 2.2 million incarcerated Americans, and you get nearly $\$ 70$ billion per year in perverse incentives directly tied to our system of imprisonment.

There is money in incarceration. This is especially true where private prison operators are able to turn a profit on the back of socially costly activity. But it is also true in fully public prison systems. For example, foodservice giant Aramark currently supplies food to over 600 prisons in North America. ${ }^{73}$ Its contract with the State of Michigan will bring it $\$ 145$ Million in revenue over three years. ${ }^{74}$ Healthcare provider

73 Alex Henderson, 9 Surprising Industries Profiting Handsomely from America's Insane Prison System, Justice Policy Institute (Feb. 18, 2015), http://www.justicepolicy.org/news/8751 (last visited Mar. 22, 2016).

74 Id. 
Corizon earns an estimated $\$ 1.4$ billion annually by providing medical services to prison systems. ${ }^{75}$ Turner Construction earned an average of \$278 million per year between 2007 and 2012 building and refurbishing prisons and jails. ${ }^{76}$ The list goes on. These are real companies with real - and massive - stakes in ensuring that the number of incarcerated Americans remains as high as possible.

The magnitude of perverse incentives is not the only factor relevant to evaluating such incentives. It also matters where incentives lie. All other things equal, perverse incentives will likely be worse when they are held by concentrated, powerful interests. By contrast, they are less likely to be problematic when held by dispersed parties. This point is related to public-choice theories of special interest legislation. James Q. Wilson and Michael T. Hayes famously theorized that legislation is more likely to be enacted when its benefits are concentrated among relatively few actors. ${ }^{77}$ When benefits are concentrated, parties who stand to benefit will have low collective action costs to overcome in responding to incentives. Potential recipients of dispersed benefits, by contrast, must overcome significant transaction costs to organize and pursue their goals. This logic applies with equal force to perverse incentives. As incentives become more concentrated, requiring fewer coordinated actors to pursue them, they become more likely to be acted upon.

Furthermore, where parties have already made relevant investments in political clout, their marginal expenditures to act on perverse incentives are reduced. Insofar as, for example, Aramark has already invested in relationships with lawmakers and prison officials, it will be relatively cheap for it to lobby for or against specific crimerelated legislation. By contrast, parties who are not already power players in the prison and law enforcement space will have to bear significant startup costs to enact their preferred policies.

Prison promises concentrated benefits to powerful parties.

75 Meet the Medical Company Making \$1.4 Billion A Year Off Sick Prisoners, THE NATION (Oct. 8, 2013), http://www.thenation.com/article/meet-medical-companymaking-14-billion-year-sick-prisoners/ (last visited Mar 22, 2016).

76 James Kilgore, These Five Corporations Are Making Millions from Mass Incarceration, BILLMOYERS.COM (Jan. 21, 2015),

http://billmoyers.com/2015/01/21/five-corporations-youve-never-heard-makingmillions-mass-incarceration/ (last visited Mar 22, 2016).

77 See James Q. Wilson, Political ORganizations 332-37 (1995); Michael T. HAYES, LOBBYISTS AND LEGISLATURES 99-126 (1981). 
Administration of the prison system requires innumerable goods that can be produced on an industrial scale. Prisons require raw materials and construction services. They must also provide for the needs of their inmates, including food, clothing, hygiene products, telecommunications, exercise equipment, and the like. All of these goods can be most efficiently provided by corporate entities specifically designed to do so. And such corporations can provide these goods and services nationally. Companies like Aramark, Corizon, and Turner Construction make millions by capturing huge swaths of the national prison market for their respective goods and services. This effectively concentrates huge perverse incentives in a small number of hands.

Furthermore, companies like these are heavily invested in political influence. Past investments lower the prospective costs of influencing crime policy. As such, these companies are likely to respond with particular ease to their perverse incentives. They can cheaply lobby against new laws that would reduce crime or prison populations and, thereby, profits.

These considerations are not merely hypothetical. We know that the perverse incentives associated with our prison system are powerful enough to induce truly unconscionable behavior in at least a few cases. As noted above ${ }^{78}$ in 2009 , two Pennsylvania judges responded to these incentives by taking bribes in exchange for denying teenagers' leniency petitions. $^{79}$ Those teenagers, along with the administrative fees necessary to incarcerate them, were then placed in the hands of private prison operators. ${ }^{80}$ The Pennsylvania judges also cooperated to shut down the only local public youth incarceration facility, thereby helping to ensure that the crooked prison operators would maximize the value of each denied petition. ${ }^{81}$

Parties' actions in response to these incentives need not usually - or ever - manifest themselves as overt corruption. The above tale of corrupt officials and judges is, no doubt, disturbing. But it is, in some sense, small potatoes. By contrast, federal and state criminal policies stand to affect millions, not mere hundreds, of Americans. Unfortunately, the benefits of reform to the general public are dispersed, with prisoners, who are among society's least powerful members, standing to benefit most. Benefits from the status quo, on the other hand,

8 See supra Introduction.

79 Lucas Anderson, Kicking the National Habit, 39 PUB. CON. L.J. 128 (2010).

80 Id.

81 Id. 
are concentrated in politically powerful corporate hands. Thus, one should expect that the above-discussed holders of concentrated perverse incentives will exercise an outsize influence in shaping policy.

And indeed, such groups do attempt to mold policy to serve their own ends. For example, the two largest for-profit prison companies in America have spent nearly \$35 million in lobbying and campaign donations since $1989 .{ }^{82}$ Other players in the prison industry are reported to have "supported policies that put more Americans and immigrants behind bars," including "California's three-strikes rule and Arizona's highly controversial anti-illegal immigration law." 83 They did so by "donating to politicians who support [such measures], attending meetings with officials who back them, and lobbying for funding for Immigration and Customs Enforcement." 84

Thus, the biggest effects of perverse incentives arising from our system of imprisonment are not likely to be judicial scandals or overt public corruption. They are likely to manifest quietly as the delay or denial of criminal justice reform. Because of our use of prison as a nonmonetary punishment, perverse incentives are concentrated in powerful hands. This economic scheme helps to ensure that political policies that reduce crime and incarceration are likely to be slow in coming, if they ever arrive at all.

\section{Prison and Optimal Deterrence}

As already discussed at length, the standard economic picture of criminal punishment holds that nonmonetary sanctions step in to fill a gap between the material wealth of the bad actor and the optimally deterrent punishment. ${ }^{85}$ Furthermore, an economically efficient system of criminal deterrence maximizes wealth transfers and avoids wealth destruction. Wealth transfers are virtually socially costless, while nonmonetary sanctions necessarily reduce societal wealth. So, turning again to our fictional jewel thief, an efficient criminal system will seek to transfer as much of the thief's $\$ 50,000$ net present worth as possible. This maximizes the proportion of his optimal punishment that is

82 Michael Cohen, How for-profit prisons have become the biggest lobby no one is talking about, WASH. POST: POSTEVERYTHING (Apr. 28, 2015), https://www.washingtonpost.com/posteverything/wp/2015/04/28/how-for-profitprisons-have-become-the-biggest-lobby-no-one-is-talking-about/.

83 Id.

84 Id.

85 See supra Part I. 
societally costless. For every dollar that is not transferred, a dollar's worth of wealth must be destroyed via a nonmonetary sanction.

Prison confounds the goal of maximizing wealth transfer and minimizing wealth destruction. This is because it inextricably ties together two kinds of private costs. A great proportion of imprisonment's private costs are imposed by destroying a bad actor's non-transferrable wealth. The bad actor cannot transfer his freedom of movement to his victim. But costs can be imposed on him by destroying that freedom. The same goes for his freedom of association, privacy, choice, and the like. However, this is not the only kind of private cost that prison imposes on bad actors. It also prevents them from working, ${ }^{86}$ thereby imposing economic costs on bad actors in the form of lost wages. In doing so, however, it destroys money that bad actors could otherwise have earned and transferred. By necessarily destroying both nontransferable and transferrable wealth, prison binds together two kinds of punishments that would be more efficiently treated separately.

One could imagine systems of criminal law that used imprisonment as a sanction but tried to avoid this problem. First consider a legal system that would not imprison bad actors immediately following conviction. Instead, it would allow them to live in society and work, transferring a large portion of their wages to their victims or the government. If bad actors earned enough to pay the private costs required for optimal deterrence, they would be free to go. Under the economic theory of criminal law, no nonmonetary punishments would be required. On the other hand, if bad actors became unable to work because of injury or old age before paying the required private costs, prison would then step in to impose further costs.

Under such a system, there is no unnecessary destruction of wealth from imprisonment; bad actors are only imprisoned when they would not have earned further wages, anyway. But there is likely to be significant under deterrence. As discussed in Part I.A., the private costs required for optimal deterrence are likely to be quite high. If there is still a substantial cost to be paid by the time a prisoner under this imaginary

86 Josh Kovensky, It's Time to Pay Prisoners the Minimum Wage, NeW REPUBLIC (Aug. 14, 2014) https://newrepublic.com/article/119083/prison-labor-equal-rightswages-incarcerated-help-economy. (Claiming repeatedly that prisoners cannot work while incarcerated. Strictly speaking, this is false. Many people work while in prison, but they do so in tightly circumscribed roles and at extremely low wages, ranging from $\$ .25-\$ 1.15$ per hour. Thus, it is unlikely that such prisoners come anywhere close to maximizing the value of their labor). 
system can no longer work, it is unlikely he will live long enough for the nonmonetary costs of prison to fill the gap. Thus, this imaginary system under deters bad acts.

Now imagine a second imaginary system that tries to avoid the pitfalls of the first. In this system, bad actors also continue to live, work, and transfer wealth following their convictions. But this system calculates the rate of earnings, compares it with the private costs required for optimal deterrence, and sends bad actors to prison just early enough that sufficient nontransferable wealth is destroyed to achieve optimal deterrence. Consider again a fictional jewel thief who should pay $\$ 100,000$. Assume he is 65 years of age and is expected to live to 75. Assume further that he can earn $\$ 5,000$ per year every year for the rest of his life. Finally, assume that the nontransferable wealth-free movement, association, and the like - that will be destroyed by his imprisonment is worth $\$ 15,000$ per year. To determine how many years the thief should spend in jail, the state uses the equation: $\$ 5,000 \mathrm{x}+$ $\$ 15,000 \mathrm{y}=\$ 100,000$. It solves the equation, seeking to maximize $\mathrm{x}$, while keeping $\mathrm{x}+\mathrm{y}$ less than or equal to 10 (the total number of years available to carry out punishments). The result is that the thief works for five years and is imprisoned for five years.

This looks at first like a system that achieves optimal deterrence while avoiding the unnecessary social costs associated with prison. But it isn't. Where the first imaginary system under deters bad acts, this one over deters them. This system ignores the jewel thief's lost wages while in prison when calculating his total private costs. In reality, the thief suffers a $\$ 20,000$ annual loss while imprisoned. These lost wages constitute a social loss, but they also constitute a private loss to the thief. They constitute money that he would otherwise have enjoyed. Factoring in the wages that the thief loses under the above arrangement, his total private costs are not a mere $\$ 100,000$, but a substantially greater $\$ 120,000$. Because prison tightly intertwines wage destruction with other wealth destruction, it is usually impossible to impose one kind of cost without the other.

Over deterrence is not trivial. It matters for at least two reasons. First, as punishments grow, marginal deterrence becomes difficult. ${ }^{87}$ Sanctions, both monetary and nonmonetary, have upper limits. The potential damage to be caused by bad actors is nearly limitless. It is, thus, crucial that a system of criminal law preserve distinctions in

87 See Posner, supra note 6, at 1207. 
punishment between classes of crimes. Excessive punishment makes that harder. If the punishment for every crime is death, the criminal law provides no incentive for the jewel thief to refrain from killing all witnesses to his crime.

The proper equation for achieving optimal deterrence under the second imaginary system would account for the prisoner's lost wages. The equation is, thus: $\$ 5,000 x+\$ 20,000 y=\$ 100,000$. Maximizing " $x$ " while ensuring $\mathrm{x}+\mathrm{y} \leq 10$ yields the result that the thief works for six and two thirds years and is imprisoned for three and one third years. On the one hand, this result looks more socially favorable than the first; it entails more years of productive work. On the other hand, this model is fully cognizant that any calculation of optimal imprisonment includes some destruction of otherwise transferrable wealth. In this case, the system requires the destruction of $\$ 16,666.66$ in otherwise-transferrable wages during the thief's years in prison. That's $\$ 16,666.66$ in net social costs. Thus, by attempting to avoid the under deterrence of the first imaginary system, the second imaginary system reintroduces either social loss or over deterrence.

What is the upshot of these thought experiments? They show the difficulty prison presents in imposing the most efficient mix of sanctions. Prison uniquely destroys both transferrable and nontransferable wealth simultaneously. Other nonmonetary sanctions, such as imposing physical pain, public humiliation, or compulsory public service, do not. Because of prison's binding together of these kinds of sanctions, attempts to avoid the social costs of prison tend to result in under deterrence. Naïve attempts to fix this under deterrence result in over deterrence. And any correction of over deterrence reintroduces needless social costs. The prison system needlessly complicates the process of efficiently avoiding social losses.

\section{Alternatives to Prison}

Up to this point, this paper has catalogued the inefficiencies of prison as a criminal punishment. It has argued that prison is suboptimal in four ways. First, it entails high administrative costs. Second, it needlessly reduces societal wealth by replacing costless wealth transfers with costly wealth destruction. Third, it creates significant perverse incentives by paying substantial administrative fees to relatively small groups of politically powerful entities. Fourth, it unnecessarily bundles the destruction of nontransferable with that of transferrable wealth, making it impossible to simultaneously eliminate inefficiency and 
achieve optimal deterrence.

Of course, no system is perfect. Any scheme of criminal punishment is likely to include some economic inefficiencies. Indeed, as argued above, all nonmonetary sanctions, by their very design, destroy wealth and cause social loss. Similarly, any plausible system of criminal justice will generate administrative fees and, therefore, at least some measure of perverse incentives. But are all plausible systems as abjectly inefficient as prison?

We now enter into a thought experiment. The experiment seeks to answer only one question: Given the social costs associated with prison, would an alternative system of punishment be more economically sound? As always, the aim of an economically sound system of criminal punishment is not necessarily to eliminate efficiencies and social costs. It is merely to minimize them. What alternative to our current system of imprisonment, then, would most effectively minimize the relevant costs and inefficiencies?

Any national system of criminal punishment will necessarily be complex. It will assign specific sanctions to particular crimes. It will create an infrastructure for administering those sanctions. It will develop systems under which those sanctions are supported by the broader criminal justice system, including detection, trials, and appeals. This paper does not attempt to propose an alternative to our current system of imprisonment at such a level of detail. Rather, its goal is to sketch the primary features of a more efficient system of criminal sanctions.

\section{A. Caveat}

As a caveat to the considerations below, I emphasize again the narrow scope of this thought experiment. The question addressed herein is not what system of criminal punishment is, all things considered, best, but rather what system is best from an economic or welfarist point of view. Sections below suggest that, to achieve optimal deterrence at the lowest social cost, harsh punishments that inflict physical pain on bad actors might be most efficient. There, I consider whether ancient practices like flogging or pillory could fill the societal role currently filled by prison. I also suggest modern alternatives to those more barbaric institutions. In asking these questions, I recognize the possibility of non-welfarist objections to the experiment's solution. For example, some readers may view punishments like pillory as barbaric or degrading. Flogging or forced labor may conjure the ugly specter of American slavery. These kinds of objections are important, and they 
may be forceful enough that the thought experiment's results should never be written into law.

While acknowledging the merits of such non-welfarist objections, I respond to them from within this paper's narrow, welfarist frame. I ask whether, on the margin, proposed alternatives to prison are more objectionable on non-welfarist grounds than our current system of imprisonment. The idea is that, if considerations of cruelty, barbarism, or America's history of endemic racism give us good reason to object to alternative punishments, they give us equally good reason to object to the current system. This fact might, in turn, give one reason to criticize the very foundations of our criminal justice system. One might wonder whether punishment and deterrence can be the foundation of a morally justifiable system of criminal law. These are worthy lines of inquiry, but they are beyond the scope of this paper. This paper simply assumes that punishment and deterrence must be the foundation of criminal law. Given that assumption, it proposes that, although efficient methods for achieving those goals can rightly be criticized on non-welfarist grounds, the efficient system may be, at worst, only as bad as what we have now.

Insofar as the reader disagrees, believing that the proposed alternatives are more objectionable than prison on non-welfarist grounds, the point is well-taken. The aims of economic efficiency and, for example, human dignity are not necessarily compatible. And, in some cases, it may be right to sacrifice one for the sake of the other. This paper argues that, given the proposed alternatives, such a sacrifice is not at issue here. However, it does not address what would be the right outcome, should the need for such a choice arise.

\section{B. A First Pass at Efficiency: More Efficient Prisons}

Thus far, this paper has talked as if there are only two choices for efficient criminal punishment: the system of imprisonment we use now or an alternative system that eschews imprisonment entirely. This dilemma is, strictly speaking, false. At least one other option exists: making prison itself more efficient. Could the major costs of the current prison system be reduced while preserving imprisonment as our primary form of nonmonetary punishment? They likely could, but only to a limited extent.

First, social costs are likely to remain high in any system involving imprisonment, because all such systems are likely to engender administrative and incentive costs similar to those of the current system. Where there is incarceration, there must be prisons, guards, 
administrators, food service providers, telecom providers, and the like. It is unlikely that such costs can be reduced significantly over the current system. There is already significant pressure on prisons to perform administrative functions at the lowest price possible. For example, as discussed above, the amount currently spent feeding an average prisoner is a mere $\$ 1.75$ to $\$ 2.65$ per day. ${ }^{88}$

And if administrative costs remain high, so will perverse incentives. Any system of criminal punishment involving prison will likely come with large perverse incentives that can be accumulated into relatively few hands. A national system of imprisonment raises the possibility of a national monopoly on the provision of administrative services.

It is possible that regulations could reduce interest-group power by requiring the distribution of prison-service contracts among many providers. However, such a solution presents problems. First, it is somewhat unlikely that many providers can provide prison services at the rock-bottom rates that governments and private operators demand. One advantage of national providers is the economies of scale they can achieve. Furthermore, even if prison contracts were required to be distributed into more hands, it is not clear to what extent doing so would avoid the bad effects of perverse incentives. The Wilson-Hayes model of interest group effectiveness presents interest groups along a spectrum. The more concentrated an incentive, the lower the transaction costs required for a collective response to that incentive. The perverse incentives of prison are currently extremely concentrated in the hands of companies like Aramark, Corizon, and Turner Construction. ${ }^{89}$ But even if prison contracts of a given kind were dispersed among a few dozen providers, the relevant perverse incentives would still be relatively concentrated. Such relatively small interest groups would still be subject to more concentrated incentives than, for example the American electorate at large. Thus, one would continue to expect prison industries to be quite effective in achieving their policy goals. This is to say, by breaking up big providers, one might reduce efficiency significantly, while reducing perverse effects only marginally.

Even if administrative costs could be lowered and perverse incentives curbed, it would still be difficult to substantially lower the

88 Prisoners Pay the Price of Food Cost Increases, PRISON LEGAL NEws (Mar. 21, 2016), https://www.prisonlegalnews.org/news/2013/aug/15/prisoners-pay-the-price-offood-cost-increases; PETER WAgner, THE PRISON IndeX (2003).

89 See supra Part II.B. 
intrinsic social costs of prison. As argued above, the social cost most inextricably intertwined with prison is caused by preventing inmates from working. ${ }^{90}$ Some of these costs could, perhaps, be mitigated by forcing prisoners to work while incarcerated. ${ }^{91}$ Indeed, many current prisoners are required to work. Pursuant to federal work requirements, it is estimated that $18 \%$ of federal prisoners are employed. ${ }^{92}$ The problem with the current system, however, is that very few such prisoners are employed in anything like their highest-value occupation. Prisoners' work options are generally limited to whatever is available on site. The menial nature of such employment is reflected in prisoners' low wages; they make, at most, just $\$ 1.15$ per day. ${ }^{93}$

The current social loss of prisoners' labor could be ameliorated by creating a better match between prisoners' human capital and their opportunities for work. One could imagine a system in which a wide range of businesses competed for the labor of prisoners. This would increase the likelihood that any individual prisoner would be employed in his highest-value occupation.

One limitation of this proposal should be immediately apparent: Prisons are not optimal sites for many kinds of work. For example, some prisoners might be most valuably employed as construction workers. But unless a particular prison is in need of expansion, a prisoner cannot be employed in that occupation at his prison site. This is likely true for many jobs. Any job requiring significant industrial space, face-to-face customer interaction, or the provision of goods and services at particular locations is likely to be inaccessible to people in prison.

One can imagine a partial solution. To create a better match between available jobs and prisoners' highest-value employment, prisons could invite companies to locate job sites near prisons. One could imagine large manufacturers locating factories near prisons to take advantage of the labor available therein. Prisoners could work at such co-located job sites during the day and return to their cells in the evenings.

Such a system would likely reduce labor losses only marginally.

90 See supra Part II.A.2.

91 See generally A. Mitchell Polinsky, Prison Work Programs in a Model of Deterrence, 19 AM. L. \& ECON. REV. 391 (2017).

92 Josh Kovensky, It's Time to Pay Prisoners the Minimum Wage, New RePubliC (Aug. 14, 2014), https://newrepublic.com/article/119083/prison-labor-equal-rightswages-incarcerated-help-economy (last visited Mar 22, 2016).

93 Id. 
Only a small subset of jobs can practicably be located near a prison, and the jobs that can are not particularly likely to match prisoners' highestvalue skills. A manufacturer might, for example, locate a factory near available prison labor with relative ease. And certainly some prisoners might achieve their highest-value employment as factory workers. But many would still be significantly under utilized. Lots of prisoners would be poor factory workers but excellent truck drivers or customer service representatives or accountants. Such jobs are either difficult or impossible to accommodate on prison-adjacent sites. A model on which nearly all value-maximizing jobs are available adjacent to prisons is one on which the areas around prisons are built up in a similar manner to dense cities. This is unlikely. And even that model admits of significant losses. In the normal job market, people must often move across states or the country to maximize the value of their labor. Worker mobility is, generally speaking, much cheaper than employer mobility. Thus, it is nearly inconceivable that enough employers would to locate themselves near prisons to create labor efficiencies even approaching those of the normal job market.

Furthermore, what would be the point of locating jobs near prison sites and forcing prisoners to return home at the end of the day? One purported advantage of prison is that it keeps dangerous individuals separate from everyone else. ${ }^{94}$ But it is unlikely that, for example, a factory would be able to fill every necessary job using prison labor alone. Thus, co-located job sites are likely to be staffed by some mix of prisoners and non-prisoners, undermining prison's isolative effects. Furthermore, job sites are unlikely to be as secure as the prisons from which inmate labor is sourced. Prisoners could escape more easily from the average factory than from the average prison. Thus, another putative virtue of prisons - containment-would be lost under such a system. One might suppose that prisoners could be followed to their job sites by guards and prevented from escaping or engaging in bad behavior. But once we have committed to monitoring and controlling prisoners while outside of prison, one wonders what role is left for the prisons themselves.

Thus, improving the efficiency of prisons is, at best, a halfmeasure in promoting global efficiency in the criminal justice system. Administrative costs and perverse incentives are unlikely to be reduced, relative to the current system. Social costs from idle prisoner labor could

94 This incapacitative function of prisons is addressed and questioned in Part IV.B. 
be mitigated, but only marginally. Indeed, the more one pushes toward a reduction in idle labor, the less sense one can make of keeping prisons in the picture at all. And if prisons cannot be squared with efficiency, we might instead imagine something more radical: getting rid of them entirely.

\section{The Efficient System}

The bulk of prison's costs and inefficiencies discussed herein could be avoided under a system of criminal punishment that bore two characteristics. First, instead of locking bad actors up where they are unable to generate any wealth, the efficient system ${ }^{95}$ would allow most criminals to live as everyone else does, in apartments or houses in cities and towns. The system would then require these bad actors to work in their highest-value employment. It would transfer a significant bulk of the wages generated by that work to some combination of the bad actors' victims and the government. It would also impose movement restrictions and monitoring on working bad actors to prevent them from committing more crimes. ${ }^{96}$

Second, the efficient system would fill the gap between the prisoner's net present worth and the costs demanded for optimal deterrence with a nonmonetary sanction other than prison. From an economic standpoint, it would not much matter what nonmonetary sanction the efficient system use. The only constraint would be that the chosen nonmonetary sanction could be applied in quantities sufficient to achieve optimal deterrence. If our jewel thief must pay $\$ 100,000$ to be optimally deterred but has only $\$ 50,000$ in cash, the chosen monetary sanction must merely be capable of making him worse off by the equivalent of another $\$ 50,000$. As such, this paper does not endorse any particular nonmonetary sanction. History presents a startling array of options, including flogging, pillory, running the gauntlope, ${ }^{97}$ tarring and feathering, branding, and many more. Modern minds have concocted similarly creative sanctions, including forcing criminals to publicly carry embarrassing signs, ${ }^{98}$ mandating that they sleep in doghouses, ${ }^{99}$ or

95 As this paper's proposed alternative to prison will henceforth be called.

96 This system is discussed more fully below, in Part IV.B.

97 A nautical punishment in which the offender was stripped to the waist and forced to march slowly by all of his shipmates as they whipped him with switches. HUGH EDM. E EVERARD, HISTORY OF THOS. FARRINGTON'S REGIMENT 16 (1891).

98 See, e.g., United States v. Gementera, 379 F.3d 596 (9th Cir. 2004).

99 See Texas Con to Do Time in Doghouse, supra note 17. 
requiring them to undergo unwanted haircuts. ${ }^{100}$ If one objects to all of these, as-yet-unimagined punishments could be substituted. Many nonmonetary sanctions could impose private costs without needlessly destroying societal wealth.

The efficient system thus forces bad actors to work, transfer wealth, and submit to nonmonetary sanctions only when absolutely necessary. It is therefore likely to engender far fewer social costs than a system of criminal law relying heavily on prison.

\section{The Efficient System Avoids Unnecessary Intrinsic Social Losses}

As discussed in Part II.A, prison needlessly causes the destruction of otherwise transferable wealth. When a person is convicted and immediately sent to prison, society loses substantial future wages, including those during and after the prison term. This has the desirable effect of imposing private costs on bad actors. But it also has the unfortunate side effect of constituting a substantial social cost.

The efficient system does not suffer from this difficulty. Its primary feature is that it actually requires the bad actor to maximize his monetary wealth, rather than destroying it. By forcing the bad actor to work in whatever profession will yield the most money, the efficient system could conceivably increase societal wealth, rather than decreasing it.

Furthermore, under the efficient system, the only wealth destroyed by nonmonetary sanctions is non-transferrable wealth. All nonmonetary sanctions destroy wealth; that is their very nature. Ideally, they do so to increase private costs precisely when there is no more wealth to transfer. The problem with prison is that it needlessly destroys wealth that could be transferred to victims or the government. Alternative nonmonetary sanctions do no such thing. To be sure, they destroy wealth, but it is wealth that can only be held by the bad actor. No one but the bad actor could possess his bodily integrity or his psychological well-being. So, when a bad actor is put into physical pain or embarrassed, the only wealth destroyed is that which could not possibly be given to anyone else. This approach has two benefits: It eliminates the needless social loss associated with prison, and it increases the amount of wealth available for transfer to victims or the government.

100 See Villalva, supra note 18. 


\section{The Efficient System Can Reduce Administrative Costs and Perverse Incentives}

Prison creates particularly strong perverse incentives because of its enormous administrative costs. ${ }^{101}$ A prison system must confine, feed, bathe, and provide for every daily need of its inmates. People get paid to do those things. Thus, they benefit when crimes are committed and people are imprisoned. Because imprisonment is so resource intensive, the perverse incentives created are enormous, increasing the likelihood that they will be acted on. In addition, they are concentrated. A handful of companies can capture an entire multibillion dollar market for a given prison service. That, combined with the fact that such companies are already invested heavily in political influence, means that they regularly act on their incentives to keep crime and incarceration levels high.

The efficient system fares better than prison on at least one crucial metric: It would require substantially lower administration fees. That means that the total value of perverse incentives would be reduced and their bad effects partially avoided.

How would the efficient system reduce administrative fees? First, it would make use of nonmonetary punishments that are far cheaper to impose than prison. The alternative punishments are all conceived of as kind of "outpatient" sanctions, wherein the bad actor shows up periodically for his punishment and then goes home. Neither ancient punishment—like flogging — nor any modern alternative-like banishment to the doghouse-requires, for example, the construction of massive, high-security "housing" facilities.

Of course, the efficient system would still have to make some administrative expenditures directed toward preventing bad actors from continuing to act badly. The model requires that bad actors be able to travel to their places of employment. Thus, it also requires that they be closely monitored to prevent further bad acts. The possible means of monitoring are discussed at greater length below, ${ }^{102}$ but it is reasonable to expect that any system of monitoring would be a less costly means of crime-prevention than incarceration. For example, according to the Administrative Office of the United States Courts, our current federal systems for supervised release cost roughly one eighth as much as

\footnotetext{
101 See supra Part II.B.

102 See infra Part IV.B.
} 
incarceration. ${ }^{103}$ One eighth of the cost also means one eighth of the total perverse incentives available.

Unfortunately, the efficient system may not fare much better than the current system with regard to the concentration of perverse incentives. As with our current system, many administrative services associated with alternative nonmonetary sanctions could be performed by national companies. The efficient system may not require contractors to build prisons or provide them with telecommunications services, but it would need competent personnel to administer the nonmonetary sanction of choice. This could give rise to national companies that support the clinical administration of such sanctions. Furthermore, as discussed below, ${ }^{104}$ an optimally efficient system for monitoring bad actors would likely make use of new technologies like GPS or biometrics. Contracts to provide and manage such technologies would likely fall into the hands of a relatively small group of corporations with the requisite competencies. As with the current system such corporations would likely invest in political capital for the purpose of securing contracts. And, as with the current system, such investment could also translate into significant opposition to policies that reduce crime and its punishment.

While the efficient system does not reduce the size of administrative costs and perverse incentives to zero, it is likely to reduce them significantly as compared with prison. Lower administrative costs mean fewer perverse incentives and, as a result, fewer perverse outcomes. Unfortunately, the efficient system does not fare much better than prison from the perspective of perverse incentives' concentration. The efficient system-and, likely, any national system of criminal sanctions - creates opportunities for a few politically powerful players to reap significant benefits. This fact, however, does not negate the efficient system's superiority to the current system. It reduces these social costs to the extent possible. That is all an economic analysis can ask.

103 Supervision Costs Significantly Less than Incarceration in Federal System, ADMIN. OFF. OF THE U.S. COURTS (2013), http://www.uscourts.gov/news/2013/07/18/supervision-costs-significantly-lessincarceration-federal-system.

104 See infra Part IV.B. 


\section{The Efficient System Does Not Conflict with Optimal Deterrence}

Part II.C. showed that attempts to reduce the social costs of prison from wealth destruction necessarily interfere with optimal deterrence. This was because prison inextricably bundles two kinds of private costs: the destruction of non-transferrable wealth and the destruction of transferrable wealth. Systems that include prison but focus only on avoiding wealth destruction end up under deterring bad acts. By contrast systems that attempt to partially mitigate prison's social costs while keeping a naïve eye toward optimal deterrence can end up over deterring them.

The efficient system suffers from neither difficulty. That is because it fully decouples the destruction of non-transferrable wealthheld in forms like bodily integrity, freedom of movement and association, and psychological ease-from the destruction of transferrable wealth-held in the form of money and other alienable property. When a bad actor is subjected to alternative nonmonetary sanctions, that event does not necessarily destroy any transferrable wealth. ${ }^{105}$ Thus, it is a simple matter to optimize the mix of monetary and nonmonetary sanctions, minimizing social costs while achieving optimal deterrence.

To illustrate the point, consider again the fictional jewel thief. Again, assume his net present worth is $\$ 50,000$ and that this figure includes all of his future wages. Assume again that the private costs that will optimally deter him from jewel thievery are $\$ 100,000$. Under the efficient system, minimizing social costs while sentencing him is simple. First, force him to work as much as possible and then transfer his material wealth to victims or the government. This allows us to impose a $\$ 50,000$ at no cost to society. Then, simply impose your nonmonetary sanction of choice in a sufficient amount to destroy $\$ 50,000$ worth of his nontransferable wealth. At no point are we forced, for example, to destroy otherwise-available societal wealth for the sake of optimal

105 One could, of course, argue that any non-wealth generating, compulsory activity constitutes a social opportunity cost. That is to say, insofar as the person in the pillory could be working, alternative nonmonetary punishments are just as bad as prison. This is technically right, but unrealistic. As discussed below in Part IV.D., there are limits to the amount that a person can or should be made to work, even when that person is a convicted criminal. This is both a moral and an economic point. And insofar as there are waking hours in which a bad actor should not be made to work, these social opportunity costs cease to exist. 
deterrence. Voila! The thief is optimally deterred at no unnecessary social cost.

\section{OBJECTIONS AND ANSWERS}

The previous Part drew only a rough sketch of an alternative system to imprisonment. That sketch included two essential elements of such an efficient system: First, instead of imprisoning bad actors, it would allow them to live wherever high-value employment was available to them. The system would force bad actors to work in the highest-paying jobs possible, while transferring a significant portion of the wealth earned therein to victims or the government. Because this would entail bad actors' continued interactions with society at large, the efficient system would also include monitoring of convicted bad actors to reasonably reduce future crimes. Second, the efficient system would impose nonmonetary sanctions other than prison to the extent necessary for optimal deterrence.

That barebones characterization of the system is open to a number of objections. It is also open to a wide range of specific implementations. This Part elaborates both. It considers possible objections to the efficient system and, where helpful in answering them, it suggests details as to how the system could be implemented. Note, however, that these detailed suggestions for implementation are not integral to the project. If other specific modes of implementation would be more practicable, all the better. All that matters for the efficient system is that it conform to the two essential conditions sketched above.

\section{A. Objection: The Efficient System is Illegal, Immoral, or Both}

Both of the efficient system's key elements raise important legal and ethical objections. This section considers and responds to the moral and legal cases against such prison's alternatives. Where necessary, it treats moral and legal considerations together because, in some cases, as with Eighth Amendment jurisprudence, the inquiries run together.

\section{Is the Efficient System's Forced Work Component Illegal Involuntary Servitude Under the Thirteenth Amendment?}

We begin with an easy objection. The Thirteenth Amendment reads, "Neither slavery nor involuntary servitude, except as a punishment for crime whereof the party shall have been duly convicted, 
shall exist within the United States."106 The question of the efficient system's legality under the Thirteenth Amendment can be easily divided into halves. The first question is whether the efficient system includes an element of involuntary servitude. Certainly it does. But is that servitude illegal under the Thirteenth Amendment? Certainly not. By its plain language, the Constitution permits involuntary servitude for duly convicted criminals. The efficient system contemplates forced labor in exactly that circumstance. Thus, there is no Constitutional challenge to the efficient system under the Thirteenth Amendment.

\section{Is the Efficient System Immoral Because of its Similarities to Systems of Indentured Servitude and Slavery?}

In The New Jim Crow: Mass Incarceration in the Age of Colorblindness, ${ }^{107}$ Professor Michelle Alexander argues that the American criminal justice system's mass incarceration of minorities amounts to a new kind of slavery. ${ }^{108}$ And many other scholars have documented the racial imbalances in arrest, conviction, and sentencing. ${ }^{109}$ These are serious critiques raising important questions about how American society ensures equal treatment under the law. Are they also important critiques of the efficient system?

At first blush, I note that these critiques are somewhat orthogonal to the purposes of this paper. The goal of this paper is not to ask how the American system of criminal justice could be more just or equitable. It asks about efficiency. Both are admirable goals toward which the system should strive. Nothing about any drive toward racial justice in policing or conviction undermines the goals of the efficient

106 U.S. CONST. amend. XIII.

107 Michelle AleXander, The New Jim Crow: Mass InCARCERAtion IN the Age of COLORBLINDNESS (2012).

108 See generally id.

109 See generally, e.g., Shima Baradaran, Race, Prediction, and Discretion, 81 Geo. WASH. L. REV. 157 (2013); Robert J. Sampson \& Janet L. Lauritsen, Racial and Ethnic Disparities in Crime and Criminal Justice in the United States, 21 CRIME \& JUST. 311 (1997); Sonja B. Starr \& M. Marit Rehavi, Mandatory Sentencing and Racial Disparity: Assessing the Role of Prosecutors and the Effects of Booker, 123 YALE L.J. 2 (2013); Cassia Spohn, Race, Crime, and Punishment in the Twentieth and Twenty-First Centuries, 44 CRIME \& JuST. 49 (2015); Alfred Blumenstein, On the Racial Disproportionality of United States' Prison Populations, 73 J. CRIM. L. \& CRIMINOLOGY 1259; Rachel A. Harmon, Why Arrest?, 115 Mich. L. REV. 307 (2016); Rachel A. Harmon, Federal Programs and the Real Costs of Policing, 90 N.Y.U. L. REV. 870 (2015). 
system. Indeed, there is little reason to think that an instantaneous replacement of the current system of prison with the efficient system would have any effect - positive or negative — on racial imbalances in arrest, conviction, or sentencing. The efficient system considers only what comes after these events. And insofar as there is an economic welfarist analysis to be made about mass criminalization, it likely favors substantial reform. It is, for example, unlikely that low-level drug crimes cause insufficient social harm to warrant any deterrent sanction at all.

Still, the worry remains. The United States' long-term maintenance of slavery is perhaps its greatest sin. It is, thus, uncomfortable to advocate a system wherein prisoners - an outsize proportion of whom are African American ${ }^{110}$ — would again be forced to work against their will. But it is important here to disaggregate two questions: Who should be punished? And what kinds of punishments should be used? The efficient system is meant to answer only the second question. Critiques like Alexander's stem primarily from America's unsettling answer to the first.

Thus, the moral question confronting the forced labor prong of the efficient system is just this: In principle, holding aside racial imbalances in policing and conviction, is forced labor an immoral criminal sentence? Most would probably say that it is not. Our general intuition is that criminal punishment must be at least somewhat harsh. This conforms to the economic logic of optimal deterrence. If punishment is not at least somewhat unpleasant, it serves no deterrent purpose. It may not be punishment at all. With these considerations in mind, it seems unlikely that forced labor, so long as it is humane, approaches the moral limit of punishment.

In any case, any non-welfarist objection to the efficient system's labor requirement should apply with equal force against systems of forced labor currently employed in American prisons. In 1990, the United States Congress passed the Crime Control Act, providing that "[i]t is the policy of the Federal Government that convicted inmates confined in Federal prisons, jails and other detention facilities shall work." 111 The law excused from forced labor only those who were seeking education, posed security risks, were physically unable, or were

110 See Inmate Race, FEDERAL BUREAU OF PRISONS, https://www.bop.gov/about/statistics/statistics_inmate_race.jsp (last visited May 6, 2016) (showing race breakdown for population incarcerated in federal prisons).

111 Crime Control Act of 1990, Pub. L. No. 101-647, § 2905, 104 Stat. 4789, 4914 (1990) (codified as 18 USC $4121 \S 2905$ note (1990)). 
subject to certain disciplinary actions. ${ }^{12}$ Many states have similar work requirements. ${ }^{113}$ As such, in 2014, 18\% of the United States' 2.4 million prisoners were subject to forced labor. ${ }^{114}$

Thus, the main difference between the current system and the proposed efficient system is not whether prisoners work, but where they work. Under the current system, prisoners work at menial tasks for paltry wages, ${ }^{115}$ producing little economic wealth. According to one prison operator, an entire year's labor from a single prisoner produces a net benefit to the prison system of just $\$ 5,000 .{ }^{116}$ By contrast, under the efficient system, bad actors are put to work in whatever job maximizes the value of their labor and demands the highest wage. This labor serves both to increase societal wealth and to maximize victims' recovery. As such, if there is any objection to the efficient system's forced labor requirement, that objection must be all the stronger against the current system's less efficient, but otherwise identical, labor requirement.

\section{Is the Efficient System Immoral Because it Treats the Rich and Poor Differently?}

The efficient system imposes nonmonetary sanctions only to fill the gap between bad actors' ability to pay and optimal deterrence. Because of this, a rich bad actor and a poor bad actor who have committed the same bad act will sometimes be treated differently. The rich actor's punishment will largely take the form of a monetary transfer, while the poor person may be subject to significantly greater nonmonetary sanctions. One might argue that this unequal treatment is morally objectionable.

The first point to notice here is that this, like the previouslydiscussed normative objections to the efficient system, is a non-welfarist concern. In principle, the efficient system imposes precisely the same amount of private costs on the rich and poor actors. By the efficient system's terms, the magnitude of the punishment does not vary with wealth, only the form. One could object to this characterization, arguing that even a large fine is less injurious to a rich man than a small amount

$112 I d$.

113 Kovensky, supra note 86.

114 Id.

115 See id. (listing the maximum prisoner's wage at $\$ 1.15$ per hour).

116 Russell Nichols, Working Prisoners Save Taxpayers' Money, Governing (May 2011), http://www.governing.com/topics/public-workforce/working-prisoners-savestaxpayers-money.html. 
of alternative nonmonetary sanction is to a poor man. If that is true, it is because of the diminishing marginal utility of money. But a sophisticated version of the efficient system could account for this. Strictly speaking, optimal deterrence requires setting penalties in such a way that the subjective expected cost of a bad act exceeds its expected value. If a rich bad actor values money very little, then more of it must be extracted from him to achieve the same level of deterrence achieved by imposing a small fine on a poor bad actor. Thus, there is no reason, in principle, to think that the efficient system requires the poor to suffer more for their crimes than the rich.

Nevertheless, one might argue that a non-welfarist value of equality requires that both the magnitude and form of punishment be the same for everyone, regardless of class. This paper does not attempt to fully rebut such an argument, but it does note the argument's significant implications for efficiency. Suppose all perpetrators of a given crime must be punished in exactly the same way. Then, the monetary transfers that can be imposed as punishment for a given crime are indexed to the poorest person who might commit the crime. For most crimes, that poorest person will likely have no wealth at all. This is essentially an argument that the law should exclusively impose nonmonetary sanctions to achieve deterrence. And as we know, nonmonetary sanctions are inherently more socially costly than wealth transfers. Thus, imposing this kind of equality drastically reduces efficiency.

Furthermore, the position requiring equality in form of punishment is radical. If we assume that tort and criminal regimes work together to achieve optimal deterrence, the argument entails a virtual elimination of tort law. This is because, whenever tort law exists, the rich can be deterred more than the poor via civil penalties. This logically means that they should be subject to fewer nonmonetary sanctions. Alternatively, if the argument is not meant to touch tort law, it entails that the rich pay doubly for their crimes. They first pay in the form of higher tort payments and then in the form of criminal sentences identical to those of the poor. Either outcome is surprising and, perhaps, worrisome.

These are difficult considerations, and they are not resolved definitively here. For now, it is sufficient to say that efficiency and absolute fairness regarding form of punishment are irreconcilable. Any increase in one requires a decrease in the other. Furthermore, a regime that insists on total fairness of this requires either the elimination of tort law or the arbitrary and inefficient increase of punishments for the rich. 
For these reasons, it is at least plausible to think that thoroughgoing equality in form of punishment is unworkable. The efficient system at least offers equality in magnitude of punishment, and perhaps that is the best we can do.

\section{Is the Efficient System Either Unconstitutional or Immoral Because it Amounts to Cruel and Unusual Punishment?}

Thus far, this paper has listed relatively few alternative nonmonetary punishments as substitutes for prison. Those listed have largely included old-fashioned and, perhaps, shocking practices. To the modern sensibility, ancient punishments compatible with the efficient system-flogging, for example - might seem cruel or barbaric. Some might argue that this makes them impermissible, either as an ethical or a constitutional matter. It is important to emphasize again that the central features of the efficient system do not commit it to any particular nonmonetary punishment. As will be discussed at length below, historical punishments might enjoy a legal advantage under certain interpretations of the Eighth Amendment, but they are by no means integral to the efficient system.

In principle, the efficient system need not be shackled to punishments of the past. This article has already mentioned new and creative nonmonetary punishments actually dreamed up by judges at sentencing hearings. They include: forcing criminals to publicly carry embarrassing signs, ${ }^{117}$ mandating that they sleep in doghouses, ${ }^{118}$ and requiring them to undergo unwanted haircuts. ${ }^{119}$ But nothing about the proposed system necessitates that the innovation stop there. These listed creative sanctions are mild compared to either imprisonment or historical sanctions like flogging. Thus, they may not be sufficiently harsh to fill the gap between bad actors' monetary wealth and optimally deterrent sanctions. If that is the case, the proposal allows for other newly invented sanctions. There may, for example, be comparatively sterile, medical methods for inducing physical or psychological discomfort. If these are less-shocking substitutes prison's deterrence, the system permits them.

There are two central points here. First, it is outside the scope of

117 See, e.g., Gementera, 379 F.3d 596.

118 See Texas Con to Do Time in Doghouse, supra note 17.

119 See Villalva, supra note 18. 
this paper to consider whether achieving optimal deterrence by imposing distress - physical, psychological, or otherwise - is ultimately morally justifiable. Rather, insofar as such impositions are a central feature of our current system of criminal punishment, this paper assumes their necessity. Second, once that necessity is assumed, the efficient system takes no inherent position on the kind or magnitude of discomfort that the law should impose. Perhaps the private costs currently imposed by imprisonment are much too high. In that case, alternative nonmonetary sanctions could be much less harsh. If mere trivial embarrassments turn out to be enough to deter some crimes, then the system endorses them. If harsher punishments comparable in magnitude to imprisonment are required for deterrence, then they are what the system demands.

Moving on to law, are the nonmonetary sanctions proposed under the efficient system illegal under the Eighth Amendment's prohibition of "cruel and unusual punishments?"120 At least one modern Supreme Court Justice has argued that the Eighth Amendment permits such sanctions, at least if they are sufficiently ancient. Because historical punishments like flogging and pillory were common in Colonial America, ${ }^{121}$ they present a plausible case for legality under an originalist reading of the Constitution. In his 1988 Taft Lecture, Justice Antonin Scalia considered what would happen if some state enacted a law punishing some crimes with flogging. ${ }^{122}$ Justice Scalia admitted that, assuming flogging was not considered cruel and unusual in 1791, an originalist reading of the Constitution could not coherently demonstrate its illegality. ${ }^{123}$ One could, Scalia supposed, read "cruel and unusual" as a phrase with evolving meaning, referring the reader to contemporary sensibilities. ${ }^{124}$ But he saw no principled textual or historical reason to do so. ${ }^{125}$ Because of this, he concluded that it would be improper to read the text of the Eighth Amendment in this way, because doing so would open up the text of the entire Constitution to ahistorical analysis. ${ }^{126}$ Thus, by Scalia's logic, a thoroughgoing originalist would be obliged to uphold the constitutionality of some harsh historical punishments.

120 U.S. CONST. amend. VIII.

121 James A. Cox, Bilboes, Brands, and Branks, Colonial WilliamsBurg Journal (Spring 2003), http://www.history.org/foundation/journal/spring03/branks.cfm.

122 Antonin Scalia, Originalism: The Lesser Evil, 57 U. CIN. L. REV. 849, 861 (1989).

123 Id.

124 Id.

$125 I d$.

${ }^{126} \mathrm{Id}$. at 862. 
Perhaps surprisingly, Scalia doubted whether he could bring himself to uphold a law imposing flogging as a criminal punishment, and he doubted whether any federal judge would do otherwise. ${ }^{127}$ In making this concession, Scalia dubbed himself a "faint-hearted originalist." ${ }^{28}$ Perhaps Scalia's doubt that any federal judge would sanction flogging and its ilk cuts against the legality of such nonmonetary sanctions. But then, perhaps Scalia was wrong to doubt. More recent originalists appear to be less faint-hearted, and they have critiqued Scalia for being so. ${ }^{129}$ Thus, it is not entirely beyond reason to think that an originalist court would uphold the use of historical nonmonetary in the implementation of the proposed efficient system.

What if one isn't an originalist or is a Scalian "faint-hearted" originalist? How do the nonmonetary sanctions suggested by the efficient system fare under the Eighth Amendment? Because we now abandon originalist analysis, we can also abandon our brief commitment to historical punishments. Aside from their legal advantage under originalism, there is no reason to prefer them over modern or as-yetundevised nonmonetary sanctions.

In Furman v. Georgia, ${ }^{130}$ Justice Brennan's concurrence argued that that there are "four principles by which we may determine whether a particular punishment is 'cruel and unusual.",131 These include whether a punishment is: (1) "by its severity be degrading to human dignity," (2) "obviously inflicted in wholly arbitrary fashion," (3) "a severe punishment that is clearly and totally rejected throughout society," or (4) a "severe punishment that is patently unnecessary."132

The efficient system faces no challenge from either (2) or (4). With regard to (4), necessity is the touchstone of the optimal deterrence at which the efficient system aims. The system's goal is to impose private costs on bad actors in precisely the amount necessary to achieve optimal deterrence; no more, and no less. Nor does the efficient system promote arbitrary punishment in violation of factor (2). Arbitrariness arises when those who have committed similar bad acts are not sanctioned similarly. Then, their punishment "smacks of little more than

127 Id. at 861.

128 See Scalia, supra note 122 , at 862.

129 See, e.g., Randy E. Barnett, Scalia's Infidelity: A Critique of "Faint-Hearted" Originalism, 75 U. CIN. L. REV. 7, 7-24 (2006).

130 Furman v. Georgia, 408 U.S. 238 (1972).

131 Id. at 281.

${ }^{132}$ Id. 
a lottery system."133 A punishment is arbitrary when, as compared with the circumstances in which is legally available, its actual use is "“freakishly' or 'spectacularly' rare." 134 The proposals of the efficient system do not run any special risk in this regard. Indeed, since its aim is always optimal deterrence, it treats all bad actors identically. It simply multiplies the benefit of the bad act to the bad actor by the probability of detection, thereby determining the total private costs to be imposed. From there, the system is perfectly content to impose the same type of nonmonetary sanction on all bad actors. The mode of an individual's punishment need never be rare.

A measure of constitutionality related to (2) might be the proportion of crime to punishment. Though the idea that the Eighth Amendment contains a proportionality requirement is controversial, ${ }^{135}$ the Court has at least held that the Eighth Amendment "forbids... extreme sentences that are 'grossly disproportionate' to the crime."136 Again, the efficient system advocates sanctions at precisely the level of optimal deterrence. This means that sentences will always be in proportion to the benefit a bad actor receives from his acts. In fact, they will be in a very specific proportion to that benefit: namely, the proportion fixed by the rate of detection and punishment.

Conceivably, if the level of detection of bad acts were extraordinarily low, optimal deterrence would demand extraordinarily harsh sanctions. This could result in a punishment "grossly disproportionate" to the crime. But the efficient system shies away from this outcome for two reasons. First, it undermines marginal deterrence. When sanctions for small crimes are too high, it becomes difficult to raise the bar for worse offenses and generate marginal deterrence. Second, recent empirical research shows that increasing the certainty of punishment has a greater deterrent effect than increasing its severity. ${ }^{137}$ This is most likely due to bad actors' rational discounting of costs in the

133 Id. at 293.

134 Id.

135 Compare John F. Stinneford, Rethinking Proportionality under the Cruel and Unusual Punishments Clause, 97 VA. L. REV. 899, 926-61 (2011) with Harmelin v. Michigan, 501 U.S. 957, 978 n. 9 (1991).

136 Harmelin, 501 U.S. at 1001.

137 See generally ANTHONy Von Hirsch et AL., CRiminal Deterrence AND SENTENCING SEVERITY: AN ANALYSIS OF RECENT RESEARCH (1999) (analyzing a crosssection of studies documenting the effects of increased sentences and increased detection on crime rates); Daniel S. Nagin, Deterrence: A Review of the Evidence by a Criminologist for Economists, CRIME AND JUSTICE: AN ANNUAL REVIEW (forthcoming). 
distant future. Given even a low discount rate of, say, 5\% annually, a bad actor might well view the total cost of a 20 -year sentence as lower than that of a 10-year sentence. This could be the case if the latter was a certainty and the former only 50\% likely. Alternatively, the effect might be explained using the "availability heuristic," whereby humans' subjective estimates of probability increase when they can easily recall similar events. ${ }^{138}$ Thus, bad actors will overestimate the probability of their own punishment when they are aware of lots of others being punished for similar acts. An efficient system of criminal punishment would be happy to take advantage of this effect. If human mistakes result in greater deterrence than expected following increased enforcement, the system should increase enforcement and reduce sanctions.

This just leaves factors (1) and (3) from Justice Brennan's concurrence. For our purposes, the two run together. While a sanction that is "degrading to human dignity" may not necessarily be "totally rejected throughout society" (or vice-versa), one might give society the benefit of the doubt by equating the two. These two tests appeal most directly to modern morality. In Furman, Justice Brennan explicitly invoked contemporary societal norms in evaluating sanctions under the Eighth Amendment. He wrote that the "[c]lause "must draw its meaning from the evolving standards of decency that mark the progress of a maturing society." "139 Other Justices have thought the same. ${ }^{140}$

The question, then, is whether, according to contemporary moral standards, the nonmonetary sanctions proposed under the efficient system either degrade human dignity or should be totally rejected by everyone. This seems unlikely. Recall that the efficient system would accept any nonmonetary sanction that avoids the destruction of transferrable wealth and achieves optimal deterrence.

Certainly, the sanctions implemented under the efficient system will sometimes have to be harsh. That is because any criminal punishment must sometimes be harsh. Bad actors may do very bad things, and optimal deterrence requires that the private costs imposed on them be even higher than the costs they impose on others. To that end, historical punishments like flogging can certainly rise to the requisite level of harshness. But if these are too gruesome to the modern

138 April M. Perry, Guilt by Saturation: Media Liability for Third-Party Violence and the Availability Heuristic, 97 Nw. U. L. REV. 1045 (2003).

139 Furman, 408 U.S. at 242 (quoting Trop v. Dulles, 356 U.S. 86, 101 (1958)).

140 See, e.g., Trop, 356 U.S. at 101. 
sensibility, other sanctions could be used. If physical pain is the right type of sanction to impose, it is surely not beyond medical science to invent new methods for inducing bodily discomfort while avoiding longterm harm. If physical constriction is the right kind of sanction, the system could take a page from the judge who ordered doghouse slumber and force bad actors to spend time in confined spaces. The law could restrict freedom of association, geographically separating bad actors from family and loved ones and restricting time spent forming new social relationships. The efficient system allows us to choose the least offensive effective option.

Even the least offensive nonmonetary sanction is likely to be harsh, but that is not a feature unique to the efficient system. It is a feature of any system of criminal punishment. Optimal deterrence demands harsh sanctions. Any moral objection to the efficient systemwhich allows for any suitable nonmonetary sanction-is, then, an objection to the entire idea of nonmonetary sanctions.

It would be difficult to argue, under Justice Brennan's first and third factors, that our current system of imprisonment represents the only form of nonmonetary sanction that respects human dignity and is acceptable to society. If anything, the conditions of prison are more degrading than anything suggested in this paper thus far. Prisoners can be subject to blanket strip-search policies following visits with outsiders. ${ }^{141}$ This is surely as humiliating as anything suggested herein. Prisoners are also much more likely to be the victims of heinous crimes than the general population. They are assaulted at over 13 times the nonprison rate. ${ }^{142} \mathrm{~A}$ staggering $4 \%$ report being sexually assaulted, representing over 30 times the non-prison rate. ${ }^{143}$ Are substantially

141 See Bell v. Wolfish, 441 U.S. 520, 562 (1979); Wood v. Hancock Cty. Sheriff's Dep't, 354 F.3d 57, 69 (1st Cir. 2003).

142 Josh Voorhees, A City of Convicts, SLATE (2014),

http://www.slate.com/articles/news_and_politics/politics/2014/06/prison_crime_rate_th e_u_s_violent_crime_rate_is_falling_partly_because_the.html (citing Census of State and Federal Correctional Facilities (2000)), U.S. DEP'T OF JusTICE (Aug. 2003), http://www.bjs.gov/content/pub/pdf/csfcf00.pdf; Uniform Crime Reports Crime in the United States, 2012, FEDERAL BUREAU OF INVESTIGATION (2012), https://www.fbi.gov/about-us/cjis/ucr/crime-in-the-u.s/2012/crime-in-the-u.s.-

2012/tables/1tabledatadecoverviewpdf/table_1_crime_in_the_united_states_by_volume _and_rate_per_100000_inhabitants_1993-2012.xls.

${ }_{143}$ Voorhees, supra note 142 (citing PREA Data Collection Activities, 2014, U.S. DEP'T OF JUSTICE (May 2014)), http://www.bjs.gov/content/pub/pdf/pdca14.pdf; Jennifer Truman, Lynn Langton, \& Michael Planty, Criminal Victimization, 2012, U.S. DEP'T OF JUSTICE (Oct. 2013), http://www.bjs.gov/content/pub/pdf/cv12.pdf. 
increased risks of indiscriminate beating or rape less degrading to human dignity than even barbaric alternatives like flogging? Are they less societally objectionable? It seems disingenuous to argue that they are. It is even more disingenuous to argue that they are less degrading than every alternative nonmonetary sanction one could imagine. These factors suggest that, if prison is not cruel and unusual by Justice Brennan's lights, neither are the alternatives proposed herein.

One worries that the principal distinction between prison and alternative nonmonetary sanctions is not morality but visibility. Prisoners are subjected to beatings, assaults, and psychological degradations, but they are subjected to them behind closed doors. The brutality of such outcomes is cloaked in the innocuous term, "incarceration." Because prisoners are out of sight, the harshness of their punishment can easily fall out of mind. This raises the possibility that the electorate systematically imposes prison sentences on individuals that are harsher than optimal deterrence requires. If the electorate can carelessly impose heavier and heavier prison sentences on prisoners without squarely confronting the true horror of prison conditions, it is also unlikely to consider carefully whether such sentences are necessary for optimal deterrence. Thus, alternative nonmonetary sanctions that wear their harshness on their face might, optimistically, force a reevaluation of the optimal level of punishment, resulting in less total suffering. And at worst, the efficient proposal suggests sanctions equally harsh to an optimally deterrent prison sentence.

An opponent of the efficient system's alternative sanctions might well regard prison, in its current form, as cruel and unusual. And given the violent conditions to which prisoners are subject, he might be right. But in order to object to the essential elements of the efficient system on these grounds, one would have to object to nonmonetary sanctions as such. The proposed system blesses any sanction with which society might be comfortable, provided it achieves optimal deterrence and does not destroy transferrable wealth. An argument that such a system is immoral is an argument that private costs should not be imposed upon bad actors at all, regardless of deterrence. This paper has no response to such an objection, but it seems unlikely that many would raise it in good faith. Bentham was right; punishment is, indeed, an evil in itself. But given humans' behavior to act badly, most would agree that it is a necessary evil. 


\section{B. Objection: Prison is Necessary for Incapacitation}

One traditional function of prison has, so far, been ignored in this paper: incapacitation. Bad actors who are imprisoned theoretically cannot commit further bad acts. ${ }^{144}$ The efficient system advocated herein demands as an essential element that bad actors are not confined in prison, but rather are put to work among the rest of us to generate wealth. If convicted criminals are not confined under the efficient system, one might worry that significantly more bad acts will occur. This would, obviously, create the very kinds of social costs that the criminal law seeks to deter.

Here, a concession must be made. The efficient system can probably not be applied to every prisoner who would currently be incarcerated. There are probably bad actors who, if allowed to live outside the secure confines of prison, would continue committing bad acts despite reasonable supervision and controls. However, the proportion of bad actors who meet this description is likely surprisingly small. It is especially small compared with the proportion of people who are currently sentenced to imprisonment.

We can estimate incapacitation's effectiveness by examining our current system of parole. A number of studies investigate whether parolees are more or less likely to commit further crimes than their nonparoled counterparts. This is, of course, not quite on point with the question of incapacitation. The primary argument of those who favor incapacitation is that, while in prison, people cannot commit crimes (at least against those outside of prison). This is obviously correct. But, for the vast majority of bad actors, prison is not forever. Nor, if the goal is optimal deterrence, should it be. Prisoners are eventually released and given new opportunities to act badly. Thus, the question that best gets at the concerns of incapacitation is which outcome-prison or releaseproduces less overall crime.

On the whole, research shows that prisoners released on parole are less likely to commit post-release crimes than those who are not. ${ }^{145}$

144 See, e.g., Arthur W. Campbell, Law of Sentencing, § 2:3 (2015).

145 See generally Melinda D. Schlager \& Kelly Robins, Does Parole Work?-Revisited, 88 THE PRISON J. 234 (2008); Ilyana Kuziemko, How should inmates be released from prison? An assessment of parole versus fixed-sentence regimes, 128 Q. J. OF ECON. 371 (2013); Robert G. Hann et al., Does Parole Reduce the Risk of Reconviction?, 30 How. J. OF CRIM. Just. 66 (1991). But see generally Amy Solomon et al., Does Parole Work?, URBAN INSTITUTE 1 (2005),

https://www.urban.org/sites/default/files/publication/51536/311156-Does-Parole-Work- 
Furthermore, some research suggests that this relationship is causal. That is, parole boards are not just picking for parole the offenders who are least likely to reoffend; something about parole itself reduces the risk of further crimes, as compared with serving a full sentence. ${ }^{146}$ So, for at least the group of inmates who are paroled, more prison would actually increase lifetime total offenses, rather than reducing them. This is no small finding. Eighty percent of American prisoners are released on parole. ${ }^{147}$ Thus, at a first approximation, for $80 \%$ of bad actors currently imprisoned in the United States, the incapacitative benefits of prison are dubious.

The efficient system can do even better. Current methods of parole are archaic. Conditions of parole basically include geographic restrictions on movement, regular drug tests, work requirements, and prohibitions from associating with those who engage in illegal activity. ${ }^{148}$ The primary enforcement mechanisms for these conditions are regular reports to and in-person meetings with Supervision Officers. ${ }^{149}$

Under the efficient system, bad actors could be monitored much more closely and their activities controlled much more tightly via the use of technology. For example, GPS ankle bracelets are already used to enforce house arrests and restraining orders. ${ }^{150}$ Such technology could be used much more extensively to enforce virtually any condition on bad actors' movement. It could automatically monitor whether bad actors were at work, at home, at school, or attending some sort of rehabilitative program, along with determining whether they were en route to some such place. If GPS bracelets seem insufficiently secure, they could be paired with, for example, biometric scanners, ensuring that the bad actor himself, and not just his GPS device, was present at the requisite location. ${ }^{151}$ Every cell phone today is equipped with the ability to

.PDF.

146 See generally Hann, supra note 145, at 66; Kuziemko, supra note 145, at 371.

147 Solomon, supra note 145, at 2.

148 See, e.g., Parole-Conditions of Release, Court Services and Offender Supervision Agency for the District of Columbia,

http://www.csosa.gov/supervision/types/parole/release-conditions.aspx (last visited Mar. 24, 2016).

149 Id.

150 See How Does A House Arrest Ankle Bracelet Work?, The Law Dictionary, http://thelawdictionary.org/article/how-does-a-house-arrest-ankle-bracelet-work/ (last visited Mar. 24, 2016).

151 See Larry Greenmeier, Security on the (Eye)Ball: Hands-Free Iris Biometrics to 
broadcast both audio and video. Any electronic equipment that bad actors would be forced to carry could be similarly equipped. Then authorities would preserve the option at any moment of dropping in on a bad actor to see what he was up to. In the most extreme circumstances, devices could be equipped with a nonlethal method of incapacitation, ${ }^{152}$ allowing authorities to remotely neutralize the bad actor, should he pose a threat to others. The list goes on. Replacing the current, antiquated methods of parole with the comparatively powerful and flexible methods available to the efficient system would almost certainly improve upon the parole system's established reductions in crime.

Not only could these technologies be used to restrict freedom in bad actors' lives, they could be used positively in conjunction with rehabilitation programs. GPS bracelets could ensure that bad actors attend therapy sessions, GED classes, or vocational trainings. Audio and visual technologies could be utilized by governmental or nonprofit organizations who seek to improve offenders' lives, giving offenders the option of reaching out when in trouble. Bad actors could actually benefit from such surveillance systems.

There will be some bad actors for whom the efficient system is inappropriate. These will primarily be individuals whose crimes are so horrific and destructive that reintegration with society would simply be too dangerous. This category is likely to include, for example, some, but not all, murderers. A certain kind of murderer-perhaps a psychopathic serial killer - may be particularly likely to kill again, regardless of monitoring or incentives to the contrary. On the other hand, other kinds of murders-perhaps those committed while in a unique state of psychological stress-may be unlikely to recur. Many may be particularly unlikely to do so if subject to mandatory psychological treatment. As always, the question of incapacitation turns on which method-prison or the efficient system-best reduces bad acts. Research suggests that, for a great majority of criminals, the efficient system wins. ${ }^{153}$

\section{Objection: Employers Will Not Hire Convicts}

People do not like to hire convicts. As discussed above in Part

Keep Bad Guys at Bay, SCIENTIFIC AMERICAN, 2012,

http://www.scientificamerican.com/article/hands-free-iris-biometrics (last visited Nov. 10, 2017).

152 See, e.g., Taser (2016), https://www.taser.com/ (last visited Mar. 24, 2016).

153 See supra Part III.C. 
II.A., this may be one of the inherent costs of prison, insofar as prison itself either decreases employability or wrongly signals not being employable. A large percentage of employers admit that they would either probably or definitely not hire an applicant with a criminal record, even for a lower-skill job not requiring a college degree. ${ }^{154}$ This fact would seem to throw a wrench into the works of the efficient system. One of its core arguments is that prison destroys value by preventing bad actors from working. But if convicted bad actors would not be able to find work, regardless of imprisonment, there is no loss.

Is there a solution? First, it is important to note that, although convicts do face increased obstacles to finding work, most are able to secure employment. According to one study, the post-conviction reduction in employment for offenders amounted to, at most, $13.8 \%$ of the total offender population of working age. ${ }^{155}$ Nevertheless, these losses are substantial, amounting to between $\$ 57$ and $\$ 65$ billion annually. ${ }^{156}$ Furthermore, even where formerly incarcerated persons are employed, it is reasonable to assume that they are often employed in lower-value work than they could otherwise secure. The efficient system's emphasis on avoiding social loss dictates that bad actors should be employed in the highest-value work practicable. How, then, can the gap be closed?

Current legislative actions suggest a solution: we could simply not tell employers whether applicants and workers are convicts. Several states have already passed so-called "ban the box" legislation, preventing employers from inquiring about potential employees' criminal histories in the early stages of the application process. ${ }^{157}$ The efficient system could extend this logic, making criminal records private and increasing the difficulty of discovering an individual's criminal past. Such privacy would not need to be indefeasible. There would, doubtless, still be situations where the publication of a bad actor's criminal history would be warranted. ${ }^{158}$ But access to criminal records would be more limited.

This suggestion will doubtless strike many-especially potential employers of individuals with criminal records-as worrisome. Employers generally prefer not to hire these people because they fear

154 Sasser, supra note 64, at 1065.

155 Schmitt, supra note 68, at 1.

156 Id.

157 See Santitoro, supra note 65.

158 For example, First Amendment freedom of the press would have to be honored. 
being victimized in the same way that formerly incarcerated individuals may have victimized others in the past. Keep in mind, however, that the efficient system emphasizes the prevention of further bad acts. It puts into place systems allowing authorities to track bad actors' every move, to check in remotely, and, if necessary, to incapacitate the bad actor. ${ }^{159}$ Furthermore, many individual's crimes have nothing to do with their work, nor are their victims in the workplace. Thus, even if some bad actors were to repeat their bad acts, it is not obvious that employer access to criminal records protects the right people.

On that note, it is highly unlikely that the general public is made much safer by its ability to access criminal records. For crimes committed between strangers, the probability that any possible victim accesses such a record, thereby avoiding a crime, is vanishingly small. And even for crimes committed between individuals with some relationship, does anyone really check to ensure that all of his friends, acquaintances, romantic partners, and business associates have a clean record? Even for those who do, the efficient system is highly concerned with avoiding future crimes by past bad actors. To that end, the most dangerous individuals would continue to be incarcerated, further reducing the benefits of public criminal records.

Returning to employers, some will take little comfort from the government's attempts to curb future crime under the efficient system. Certainly, the authorities would make reasonable efforts in attempting to avert bad acts, but the authorities are not the ones most likely to be victimized. They might therefore be under incentivized in their vigilance. The burden, though, could be shifted. Agencies that oversee the efficient system could be held liable to victims for bad acts that take place on their watch. Indeed, it makes good sense to shift possible losses to the party best positioned to prevent the harm. Under such a system, the incentives of the government would "insure" employers against the possible losses associated with hiring a bad actor. Doing so would do much to align the interests of the government and those of employers.

Government liability for bad actors' at-work crimes would also serve another purpose. It would make administrators of the efficient system especially careful not to direct bad actors into professions that genuinely would create significant risks of additional bad acts. Many crimes are not workplace-related, but some are. It would be foolish to place a person convicted of financial fraud into a position as a financial

159 See supra Part IV.B. 
advisor. Potential administrator liability would deter such an oversight. It is unfortunate that, for some bad actors, the employment in which they pose the greatest societal risk is also the employment for which they would be most highly compensated. In such cases, the efficient system merely requires placement of bad actors in the highest-value employment practicable, not the highest-value employment possible. This rule offsets social costs in the form of foregone wealth with social gains in the form of averted bad acts.

Finally, one might object that, even if criminal records are kept private, employers will still find out about bad actors' criminal records and decline to hire them. Trials, for example, are public. Moreover, they take time, and bad actors' absence from regular life during a trial might be noticed. There are two responses to this objection. First, in a world where criminal records are kept private, trial records would be stripped of identifying information. Thus, to know who was on trial, people would have to show up in person to see. Second, there is no reason to think that bad actors under the efficient system would have to be employed in a locality where community members would be familiar with their histories. Just as people can currently be imprisoned anywhere in the country, bad actors could be forced to work wherever was most sensible. Benefits might accrue to the system and to society at large from placing bad actors in communities where they have preexisting support. But doing so is far from necessary, should countervailing factors prevail.

Thus, the objection that employers will not hire bad actors has an answer: Do not tell them who has and has not been formerly incarcerated. This answer is not as wild as it might at first appear. There is no ex ante reason that a person's criminal record should be public knowledge. Indeed, similarly sensitive information, like medical records, is paradigmatic of the private sphere. The argument for public criminal records has to do with safety and, as demonstrated herein, that argument is significantly weakened by the structure of the efficient system.

\section{Objection: Bad Actors Will Not Work for Wages They Cannot Keep}

An integral component of the efficient system is that, rather than destroying the economic value of a bad actor by preventing him from working, it forces him to generate societal wealth. Happily, wealth generated by the bad actor can then be used to impose private costs on 
him by transferring that wealth to his victims or to the government. One could, however, object that bad actors are unlikely to work very hardor at all-if every dollar they earn for work is transferred to someone else.

This argument has force. It likely forms part of the logic undergirding federal law that places an upper limit on wage garnishment. ${ }^{160}$ That law sets the maximum wage garnishment at either $25 \%$ of an individual's disposable earnings or the amount by which disposable earnings exceed thirty times the federal minimum wage, whichever is less. ${ }^{161}$ It is true that bad actors would be unlikely to work if every dollar they earned was taken from them. Such high garnishments would also be counterproductive for other reasons. For example, no system of criminal punishment should sentence offenders to homelessness and starvation. A system that strives toward efficiency should doubly avoid such outcomes. It is therefore clear that, under the efficient system, bad actors would have to retain at least some of their earnings. This would help to avoid both bad actors' destitution and their complete refusal to work.

Precisely how much of a bad actor's wages would the efficient system transfer? That question is beyond the scope of this paper. However, there are a number of factors to consider. First, the federal limits on wage garnishments are designed to apply to people who have not been convicted of a crime. Such individuals enjoy Thirteenth Amendment protections. They cannot be forced to work. By contrast, bad actors under the efficient system can be forced to work. This suggests that higher proportions of their incomes could be transferred while still maintaining significant labor participation.

Second, from a social cost standpoint, we should not be indifferent to bad actors' choices between monetary and nonmonetary sanctions. The greater the proportion of optimally deterrent sanctions composed of nonmonetary punishments, the greater the social loss. Thus, it makes sense to induce in bad actors a preference for work and wealth transfer over nonmonetary sanctions. There are two ways this could be done: either by carrot or by stick. Take the optimally deterrent sanction as a baseline. Under the carrot approach, bad actors who work diligently toward generating wealth to be transferred are given a "discount" off of the optimally deterrent sanction. That discount comes

\footnotetext{
160 See 15 U.S.C. $§ 1673$ (2012).

${ }^{161} \mathrm{Id}$.
} 
in the form of reduced nonmonetary sanctions. Under the stick approach, bad actors who refuse to work diligently toward generating transferrable wealth are subject to an increase above the optimally deterrent sanction. This increase comes in the form of increased nonmonetary sanctions. The danger of the former approach is that it results in marginally under deterred bad acts. The danger of the latter is that it marginally over deters. But the costs of either under deterrence or over deterrence are likely to be justified by either scheme's positive effect on bad actors' worker productivity.

\section{CONCLUSION}

The central lesson of this paper is singular: Prison is an inefficient method for deterring crime. It unnecessarily destroys social wealth at the very same moment when other areas of the law seek to maximize it. By preventing bad actors from generating wealth, prison robs victims of their recovery and impoverishes society as a whole. The system creates other inefficiencies, as well. It generates enormous administrative costs, creates perverse incentives, and makes irreconcilable the goals of achieving optimal deterrence and minimizing social costs.

But alternatives are conceivable. Rather than being locked away to rot, bad actors could be employed productively in the workforce. The gains of that employment could be transferred to victims and governments, while simultaneously serving as a deterrent cost. And to the extent that monetary transfers cannot achieve optimal deterrence, humankind is capable of inventing alternative nonmonetary sanctions to fill the gap. Such alternative nonmonetary sanctions might rightly be criticized from a non-welfarist moral perspective. But these criticisms often apply with equal force to the current system. Where they do not, the question becomes when and whether efficiency should be sacrificed to other normative concerns. That question is outside the ambit of this paper. The alternative system can also be criticized on practicability grounds. But upon close investigation, such criticisms lose much of their force.

Taken together, then, these considerations present the question: Why have prison at all? 